\title{
31. SEDIMENTARY AND CRUSTAL STRUCTURE OF THE NORTH AOBA BASIN FROM SEISMIC REFRACTION DATA ${ }^{1}$
}

\author{
Bernard Pontoise, ${ }^{2}$ Phillipe Charvis, ${ }^{2}$ and Martine Gérard ${ }^{3}$
}

\begin{abstract}
Six long-range seismic refraction profiles were collected with ocean-bottom seismometers and a pneumatic seismic source over the central New Hebrides Island Arc during the EVA X (1982) and EVA XIII (1986) cruises. Four profiles are located in the sedimentary intra-arc North Aoba Basin and two others were shot on the western border of the North Fiji Basin. The crust of the western border of the North Fiji Basin is $8 \mathrm{~km}$ thick and has seismic velocities with clear oceanic affinities. The crust beneath the North Aoba Basin is 11 to $13 \mathrm{~km}$ thick. The sediment fill reaches $4 \mathrm{~km}$ in thickness in the central part of the basin and thins toward its eastern and western borders. A 200-m-thick high velocity layer, with a seismic velocity of $4 \mathrm{~km} \mathrm{~s}^{-1}$, can be inferred from the record sections located in the central and eastern parts of the North Aoba Basin. This high velocity layer, located between 0.7 and $2 \mathrm{~km}$ below sea-floor, can be correlated with the volcanic sill reached at Ocean Drilling Program (ODP) Site 833. The velocity vs. depth profile of the North Aoba Basin igneous crust bears oceanic characteristics, with a 7.5- to 8.5-km-thick igneous crust. The comparison of the velocity vs. depth behavior of the North Aoba Basin igneous crust with that observed in neighboring oceanic basins suggests that the crust may originate either from the North Fiji Basin or from the Pacific Plate. The North Aoba Basin appears as a large asymmetric syncline of oceanic crust bent down between the Eastern and the Western volcanic Chains rather than as a graben underlain by a thin, arc-type crust. Previous works, along with the results presented here, strongly suggest that the North Aoba Basin crust overthrusts the North Fiji Basin crust. The North Aoba Basin crust appears to be mostly thinner than the crust beneath the northern and southern segments of the arc. Assuming that island-arc plutonism and volcanic activity are important processes of intra-oceanic island-arc crustal thickening, it is unclear why the North Aoba Basin crust is thin compared to the crust of the northern and southern segments of the arc. Nevertheless, the velocity vs. depth behavior of the North Aoba Basin crust suggests that little or no island-arc plutonism affected the crust.
\end{abstract}

\section{INTRODUCTION}

We present results from two seismic refraction experiments conducted by ORSTOM on the Coriolis during the 1982 (EVA X) and 1986 (EVAXIII) marine geophysical investigations of the central segment of the New Hebrides Island Arc (Figs. 1 and 2). Seismic refraction data were collected, using ocean-bottom seismometers (OBSs) and a pneumatic sound source (Fig. 3), in the North Aoba Basin and on the western border of the North Fiji Basin.

The crustal structure of the North Aoba Basin, previously interpreted from seismic refraction data (Pontoise, 1984; Holmes, 1988), exhibits a 4- to 5-km-thick sedimentary cover overlying basement characterized by seismic velocities ranging from 4.7 to $6.0 \mathrm{~km} \mathrm{~s}^{-1}$. However, no mantle arrival was detectable on the refraction lines and the calculated crustal thickness was estimated to be minimal. Modeling of onshore and offshore gravity data (Collot and Fisher, 1988) indicates that the North Aoba Basin has a 12- to 13-km-thick crust (Fig. 4A) based on two-dimensional gravity anomaly calculations constrained by velocity vs. depth profiles deduced from seismic refraction measurements. The North Aoba Basin crust could be interpreted either as a graben (Fisher et al., 1988) associated with a thinning of the island-arc crust (Collot and Fisher, 1988) or as a fragment of oceanic crust trapped within the island arc (Collot and Fisher, 1988). The existence of an asymmetric thick crustal root across the Eastern Chain, as deduced from gravity data, supports the model of incipient back-arc thrusting along Maewo Island. Focal mechanisms from earthquakes distributed along the Eastern Chain of Maewo and Pentecost islands indicate thrust faulting (Collot et al., 1985; Louat and Pelletier, 1989; Fig. 4A). The morphology of the eastern flank of the islands and the seismic pattern support a west-dipping thrust zone. Louat and Pelletier (1989) esti-

\footnotetext{
${ }^{1}$ Greene, H.G., Collot, J.-Y., Stokking, L.B., et al., 1994. Proc. ODP, Sci. Results, 134: College Station, TX (Ocean Drilling Program).

${ }^{2}$ ORSTOM, B.P. 48,06230 Villefranche-sur-Mer, France.

${ }^{3}$ ORSTOM, Centre de Bondy, 70 Route d'Aulnay, 93143 Bondy, France.
}

mated the relative plate motions between the Pacific Plate, the Australian Plate, the New Hebrides microplate and the North Fiji Basin microplate, using shallow seismicity, focal mechanisms solutions, bathymetry, and magnetic surveys. Their reconstruction is consistent with a 1 $\mathrm{cm} \mathrm{yr}^{-1}$ convergence rate between the North Fiji Basin and the New Hebrides microplates.

We interpret here the seismic refraction data collected in the North Aoba Basin in order to define the velocity vs. depth structure of the crust, the depth of the Moho, and the two-dimensional structure of the crust along east-west and north-south cross-sections. We also reinterpret the seismic refraction lines from the EVA X experiment, located along the western border of the North Fiji Basin, to compare with the results obtained in the North Aoba Basin.

\section{GEOLOGICAL AND TECTONIC SETTING}

The central segment of the New Hebrides Island Arc is characterized by three chains of volcanic islands parallel to the general trend of the arc, the Western, the Eastern, and the Central Chains (Mitchell and Warden, 1971). A 50-km-wide, 160-km-long, intra-arc sedimentary basin, the Aoba Basin, lies on the top of the arc. This basin reaches $3000 \mathrm{~m}$ in water depth and is bounded by the Western and the Eastern Chains and crosscut by the Central Chain (Fig. 1). The Aoba Basin is divided into two parts, the North and the South Aoba Basins, by Aoba Island, which is part of the central active volcanic chain (Greene et al., 1988).

Onshore geology indicates that the Western Chain (Espiritu Santo and Malakula islands) originated during the late Oligocene to early middle Miocene (25-14 Ma) and exhibits submarine basaltic to andesitic lavas possibly related to the subduction of the Pacific Plate beneath the Australian Plate along the fossil Vitiaz Trench (Macfarlane et al., 1988). Lava clasts with island-arc tholeiitic affinities are found in volcaniclastic rocks and conglomerates in Maewo and Pentecost islands (Carney and Macfarlane, 1978). These rocks could be related to the volcanic activity that shifted from the Western Chain to the Eastern 


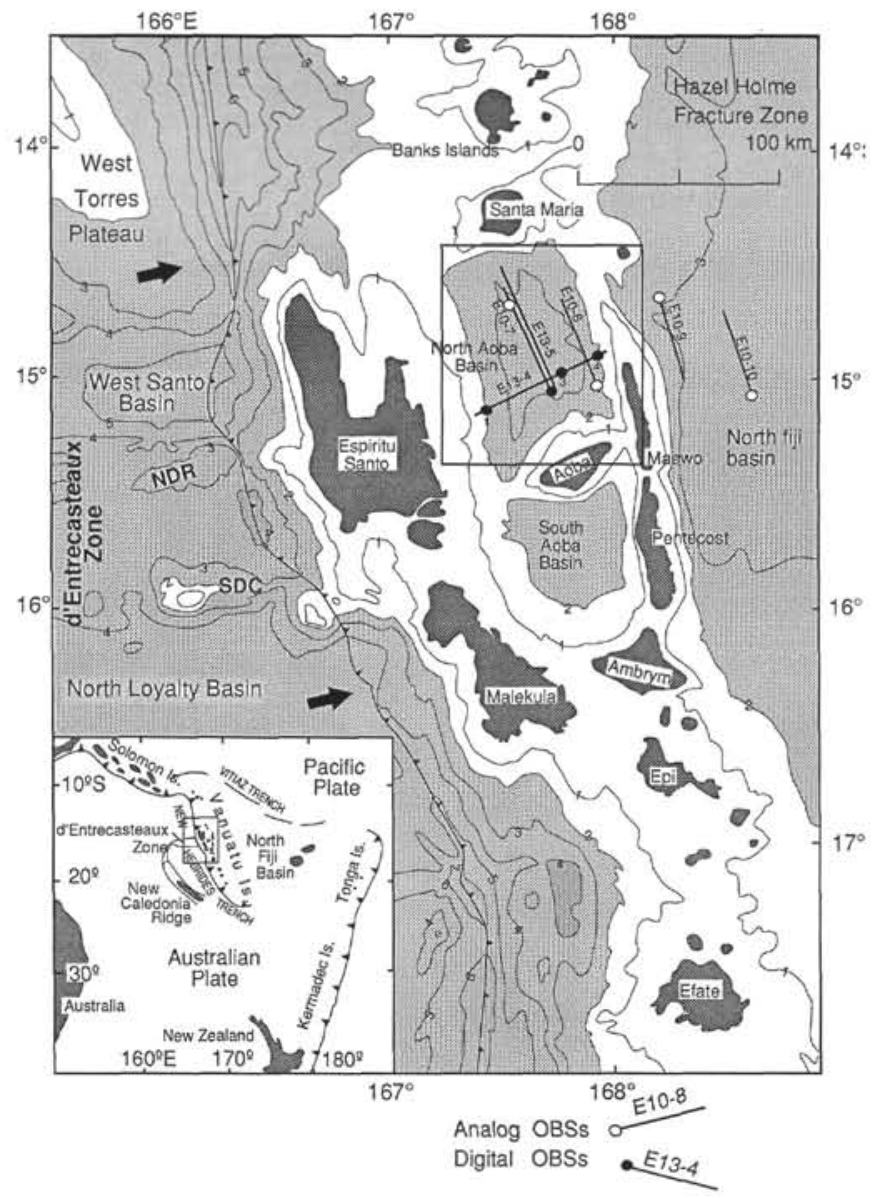

Figure 1. Location of the study area. Solid lines are seismic refraction profiles; solid circles are digital OBSs; open circles are analog OBSs. Bathymetric contour intervals are $1000 \mathrm{~m}$ and the black arrows on the subducting plate indicate the relative motion between the Australian and Pacific plates.

Chain during the early late Miocene (11-8 Ma). The shift of the volcanic line may be the result of a polarity reversal of the subduction that flipped from east to west facing (Carney et al., 1985). The initiation of the spreading in the North Fiji Basin occurred in the late to middle Miocene, as a K/Ar age of $12 \mathrm{Ma}$ was obtained on a dredge sample of MORB-type lava recovered in the Hazel Holme Fracture Zone on the western border of the North Fiji Basin (Monjaret, 1989). This late middle to middle Miocene phase of initiation of the North Fiji Basin spreading is also consistent with the analysis of magnetic data (Auzende et al., 1988). During the early Pliocene (5-4 Ma), the volcanic activity shifted from the Eastern Chain to the Central Chain, which remains active at present (Macfarlane et al., 1988). The d'Entrecasteaux Zone, a major relief of the subducting plate, is interpreted as a remnant arc of an Eocene subduction zone, and collides with the New Hebrides Island Arc (Collot et al., 1985). The collision has uplifted the Eastern and Western Chains since the middle Pliocene ( $3 \mathrm{Ma}$; Macfarlane et al., 1988) and has produced compressive tectonism that affects the North Aoba Basin (Collot et al., 1985; Daniel et al., 1989).

\section{DATA ACQUISITION AND PROCESSING}

\section{Field Experiment}

During the EVAX seismic refraction experiment, four lines (E10-7, E10-8, E10-9, and E10-10) were shot in the North Aoba Basin and in the North Fiji Basin (Figs. 1 and 2). Only one ocean-bottom seismometer (OBS) was deployed at one end of each line. The OBSs were singlechannel (vertical geophone) analog recording instruments (Latham et al., 1978). The seismic source was composed of a 16-L air gun fired every $3 \mathrm{~min}$, providing a shot spacing of approximately $550 \mathrm{~m}$ for a ship's speed of $6 \mathrm{kts}$. During the EVA XIII seismic refraction experiment, two lines (E13-4 and E13-5) were shot in the North Aoba Basin using three-component (one vertical and two horizontal geophones) digital recording OBSs (Nakamura et al., 1987). The sampling rate was 100 samples per s and the recording window length was $20 \mathrm{~s}$. The shooting line was run twice at a speed of $4 \mathrm{kts}$. During the first run, a single $16-\mathrm{L}$ air gun fired every $50 \mathrm{~s}$ provided good resolution with $100 \mathrm{~m}$ shot spacing. During the second run, two air guns of the same type were fired every $100 \mathrm{~s}$, providing a $200 \mathrm{~m}$ shot spacing with better penetration than that of the first run. The total storage capacity of the digital OBSs allows the recording of up to 866 seismograms along each line. On both of our OBS generations, seismic signals were converted from analog to digital and then buffered in order to avoid recording of mechanical noise induced by tape drives during the data recording. The recording method permitted the use of very high gains and allowed long range experiments using a small pneumatic source. On the analog OBS, seismic signal was converted back into analog form before being recorded in frequency modulation mode on standard audio cassettes. Along line E13-4, four OBSs were deployed, but only three recorded useful data. Only one station was deployed on line E13-5, as previously acquired line E10-7 had the same trackline. The seismic refraction lines E13-4 and E13-5 are located along the same tracklines as the Lee-21 (1982 cruise of the S.P. Lee; Fisher et al., 1988) and the M-1031 (1987 cruise of the Jean Charcot; Gérard, 1993) multichannel seismic (MCS) reflection lines, respectively. Leg 134 Sites 832 and 833 in the North Aoba Basin are located on the E13-4 and E13-5 seismic refraction lines (Figs. 1 and 2), respectively.

The seismic source, consisting of one or two 16-L air guns, was towed at a depth of approximately $31 \mathrm{~m}$ in order to increase the efficiency of the interferences between downgoing direct waves and surface-reflected waves (surface "ghost"). This statement is very frequency dependent; thus, the frequency enhanced by this method was about $12 \mathrm{~Hz}$. Shot pressure was set to $1800 \mathrm{psi}$. The resulting bubblepulse frequency of about $12.2 \mathrm{~Hz}$ (Fig. 3) is well adapted for our purpose of studying deep crustal structure. The characteristic bubble pulses from such an untuned air gun are an aid in detecting weak signals among background noise because of the length of the source wavelet $(0.2 \mathrm{~s}$ to $0.3 \mathrm{~s} ; \mathrm{Fig} .3)$. Although this improvement is naturally accompanied by a loss of resolution in time, the lower resolution is generally more tolerable in seismic refraction surveys than in seismic reflection surveys. Time drifts of remote OBS clocks were measured before the deployment and after the recovery of each station, and interpolated during the experiment (Nakamura et al., 1987). Transit satellite navigation was the only available positioning system in this area in the 1980s. This provided a relatively inaccurate ship location that was based on shipboard Doppler effect measurements of the satellite crystal-controlled internal oscillator. Positioning uncertainty was estimated to be more than 1 mile per kt of error in estimating the north-south component of the ship's speed. No Doppler log was available aboard the Coriolis and measured speed was surface speed; thus, absolute positioning was of poor quality. Instead of using absolute ship and station locations to determine absolute distance and azimuth from source to receiver, direct and multiple water-wave propagation times, in conjunction with measured seawater sound velocity vs. depth profiles and bathymetric profiles, were used to compute an accurate relative distance between the sources and the receivers.

\section{Data Processing}

Analog signals were played out on analog recorders through a voltage-controlled oscillator and analog amplifiers and filters. Each trace was then pasted up by hand to produce record sections. Digital records were demultiplexed, corrected for clock drifts, merged with shot instants and navigation data, and converted to SEG-Y format. Data were processed with the commercial "DISCO" seismic data 
$168^{\circ} \mathrm{E}$

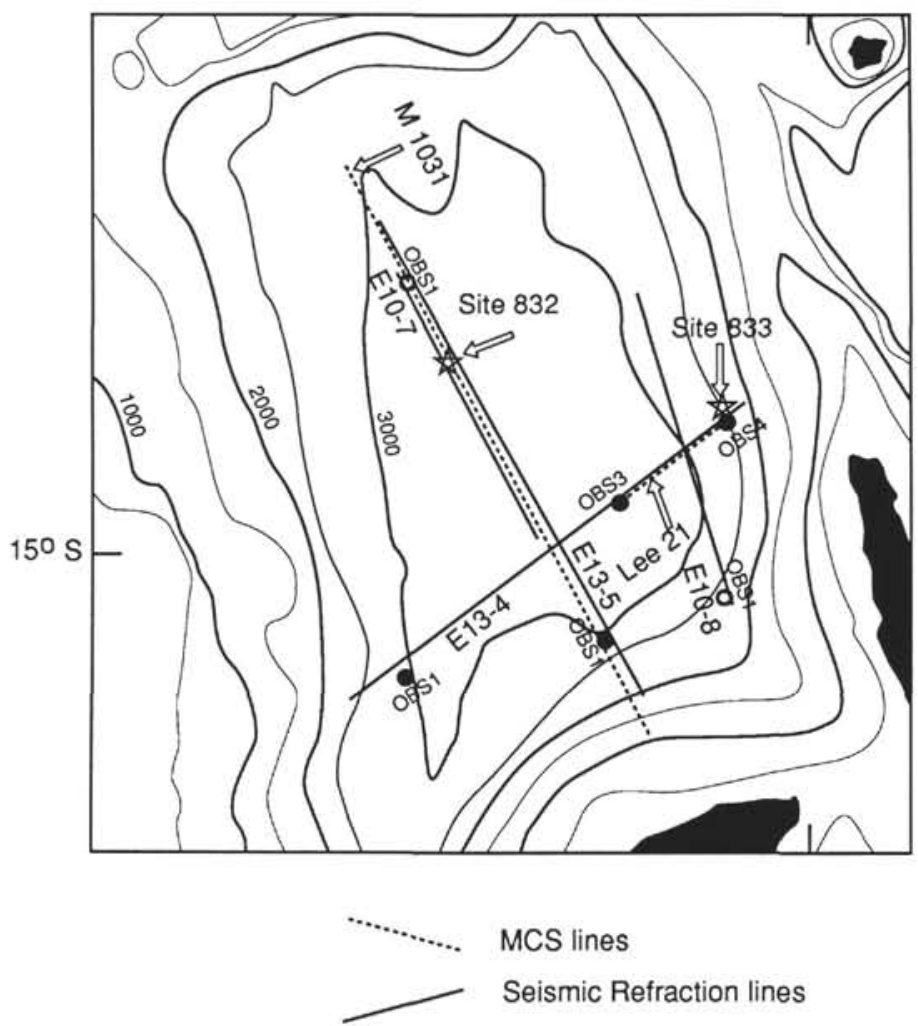

Figure 2. Schematic view of the North Aoba Basin lines presented in this paper. Continuous straight lines are seismic refraction profiles; dashed lines are MCS profiles; stars are Leg 134 Sites 832 and 833. Other symbols are the same as in Figure 1. Bathymetric contours intervals are $500 \mathrm{~m}$.

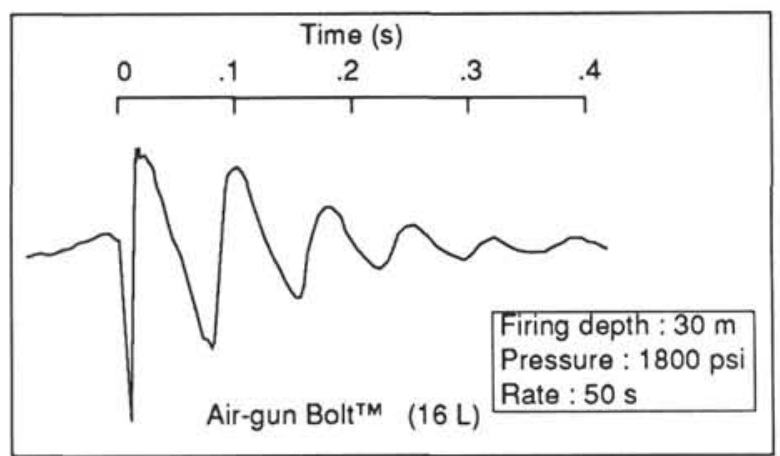

Figure 3. Source signature of one 16-L BOLT air gun as recorded with a near surface hydrophone. Note that the frequency generated by this air gun towed at $30 \mathrm{mbsl}$ and fired at $1800 \mathrm{psi}$ is about $12 \mathrm{~Hz}$ and that the frequency enhanced by these conditions is the same.

processing software package at the University of Texas Institute for Geophysics. Traces were stacked in $100 \mathrm{~m}$ bins with a velocity of $6 \mathrm{~km} \mathrm{~s}^{-1}$. Most bins contain only one or two traces. The attenuation due to arrivals with velocities different from the stacking velocity is negligible for distances shorter than $100 \mathrm{~m}$. The binned data were plotted in order to produce a basic seismic record section plot using appropriate filters and linear gains with distance and time. A deconvolution filter, based on the recorded water-wave wavelet, was applied to near-offset data for analysis of precritical reflections. Traveltimes were digitized from the record sections. A one dimensional (1D) interpretation, with horizontal layers and vertical velocity gradients, was made for single OBS lines from traveltime picks corrected for topographic effects (Fig. 5). We used a two dimensional (2D) raytracing program (Ceverny et al., 1974) to compute arrival times on the multiple OBS lines (i.e., line E13-4 and the combined lines E10-7 and E13-5; Fig. 2). This technique, applied on traveltime picks noncorrected for topographic effects, allows control of the geometry of the interfaces. A rough estimation of arrival amplitude variations along the line can be inferred from the ray density at emerging points of evenly spaced ray parameters.

\section{DATA INTERPRETATION}

We present a new interpretation of the two seismic refraction lines located on the western border of the North Fiji Basin and already described by Pontoise (1984) and Collot and Fisher (1988). We also present the two unpublished seismic refraction lines E13-4 and E13-5 located in the North Aoba Basin. These interpretations are based on ray-tracing techniques, which are a considerable improvement over the slope-intercept method and generally lead to results comparable to those obtained using full-waveform modeling (White et al., 1992). In the interpretations below, we divide the crust into sedimentary cover, upper igneous crust, and lower igneous crust. Here, the term velocity stands for the $P$-wave seismic velocity within the rocks calculated from seismic refraction data.

\section{Structure of the North Fiji Basin}

Lines E10-9 and E10-10 were shot on the western border of the North Fiji Basin, northeast of Maewo Island (Fig. 1). A 1D ray-tracing modeling was performed because only one OBS was deployed along 

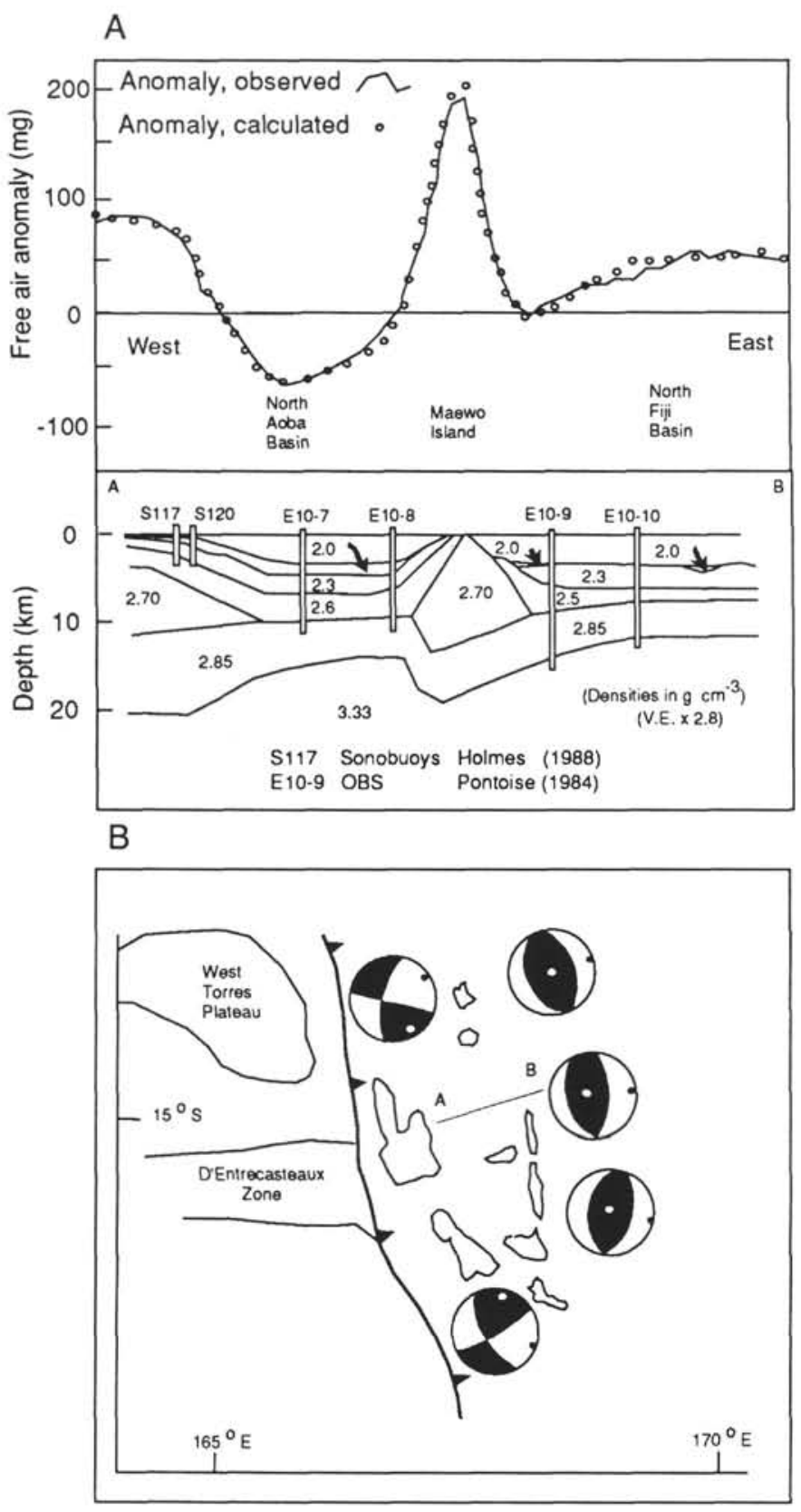

Figure 4. A. Crustal structure of the North Aoba Basin after Collot and Fisher (1988). The crustal structure has been computed using EVA-X preliminary refraction results and Lee-80 sonobuoys seismic refraction results (Holmes, 1988), together with available offshore and onshore gravity data over the central part of the New Hebrides Island Arc. B. Focal mechanisms solutions for shallow $(0-70 \mathrm{~km})$ earthquakes showing the thrust planes in the Maewo and Pentecost area (Collot et al., 1985; Louat and Pelletier, 1989). Line A-B denotes the section where crustal structure is displayed in part A.

each line (Figs. 5C and D, and 6A). Seismic units, as derived from observed traveltimes, can be divided into four units defined as follows:

1. Based on available seismic reflection data in the study area, the sedimentary cover of the North Fiji Basin is less than $0.5 \mathrm{~s}$ two-way traveltime (stwt). Our record sections do not exhibit low velocity (less than $3 \mathrm{~km} \mathrm{~s}^{-1}$ ) arrivals. Assuming a velocity of $1.9 \mathrm{~km} \mathrm{~s}^{-1}$, the thickness of the sedimentary cover, as determined from the intercept of the refracted wave in the underlying layer, varies from $0.5 \mathrm{~km}$ thick along line E10-10 to less than $0.1 \mathrm{~km}$ thick along line E10-9.
2. The upper igneous crust is divided into two layers, with velocities ranging between $3.3-3.5 \mathrm{~km} \mathrm{~s}^{-1}$ for the upper layer and between $4.8-5.2 \mathrm{~km} \mathrm{~s}^{-1}$ for the lower one. Such velocity values are characteristic of oceanic Layers $2 a$ and $2 b$, interpreted as pillow lavas and massive basaltic material, respectively (Houtz and Ewing, 1976). Alternatively, the velocities computed for the upper layer (2a) are also commonly found in layers composed of highly compacted sediments or sediments enriched in volcanic elements. The total ( $2 a$ and $2 b$ ) thickness of Layer 2 ranges from $1.8 \mathrm{~km}$ along line E10-10 to $4 \mathrm{~km}$ along line E10-9. The existence of Layer $2 \mathrm{a}$ is well documented on oceanic crust younger than $20 \mathrm{Ma}$ (Houtz and Ewing, 1976; Orcutt, 1987). The presence of a 0.7 - to $1.5-\mathrm{km}$-thick oceanic Layer $2 \mathrm{a}$, with a rather low velocity value, is consistent with the age of $12 \mathrm{Ma}$ obtained on the western border of the North Fiji Basin (Monjaret, 1989). The 1.8-km total thickness of Layer 2 along line E10-10 is compatible with the 1.6-km-thick layer 2 of the North Fiji Basin crust obtained along line E13-1 farther $200 \mathrm{~km}$ north (Sage and Charvis, 1991) and falls within the range of the standard oceanic crust (Fig. 6B; White et al., 1984). Along line E10-9, Layer 2 is twice the observed thickness of Layer 2 beneath line E10-10.

3 . The lower crust is usually better modeled by one layer with velocity gradients as shown by Spudich and Orcutt (1980). Despite the poor constraints provided by our data set, we model the lower crust along line E10-10 as a 5.5-km-thick layer with velocities ranging from $6.4 \mathrm{~km} \mathrm{~s}^{-1}$ at the top to $7.1 \mathrm{~km} \mathrm{~s}^{-1}$ at the bottom. The vertical velocity gradient is $0.13 \mathrm{~s}^{-1}$. Beneath line E10-9 the lower crust reaches $6.5 \mathrm{~km}$ in thickness, and the velocity at the top of the layer and the velocity gradient are similar to those obtained beneath line E10-10.

4. The upper mantle is characterized by velocities of 8.2 to 8.3 $\mathrm{km} \mathrm{s}^{-1}$ computed from seismic traveltimes recorded between distances 38 and $48 \mathrm{~km}$ (Fig. 5).

The total thickness of the igneous crust in the western North Fiji Basin is $8 \mathrm{~km}$ beneath line E10-10. The velocity vs. depth profile for this line lies between extreme bounds for normal oceanic crust as determined by White et al. (1984). The computed velocities are apparent velocities uncorrected for the effects of possibly dipping layers because only one OBS recorded shots along lines E10-10 and E10-9. Nevertheless, these apparent crustal velocities are similar to velocities computed in a 2D model for line E13-1 (Fig. 6A), which is located in the North Fiji Basin, $200 \mathrm{~km}$ north of our study area (Sage and Charvis, 1991). The velocity vs. depth model for line E10-10 is also similar to the one obtained farther $500 \mathrm{~km}$ south on the western border of the North Fiji Basin (Pontoise et al., 1982; Larue et al., 1982) where crustal thickness was estimated to be 7 to $8 \mathrm{~km}$. All these seismic refraction profiles are located at different latitudes on the western border of the North Fiji Basin. The similarity between the velocity vs. depth models obtained for these different seismic refraction lines attests to the homogeneity of the 10- to 12-Ma oceanic crust of the western North Fiji Basin. The total igneous crust thickness reaches $12 \mathrm{~km}$ beneath line E10-9. The thickening of the crust beneath line E10-9 compared to line E10-10 is mainly due to the thickening of Layer 2 (2.2 times thicker), as Layer 3 is only 1.3 times thicker beneath line E10-9 than beneath line E10-10.

\section{Structure of the North Aoba Basin}

The structure of the North Aoba Basin is mainly based on 2D modeling of the data recorded along line E13-4 (3 OBSs) (Figs. 2, 7A and $\mathrm{B}$, and $8 \mathrm{~A}$ ) and along line E13-5 (Figs. 2 and $8 \mathrm{~B}$ ). For 2D modeling, we combined the data recorded on the E13-5 digital OBS (southern OBS1, Fig. 2) with the data recorded by the analog E10-10 OBS (northern OBS1, Fig. 2). We divide the description of the different units into sedimentary units and crustal units. The sedimentary structure is obtained from combined seismic refraction data and ODP Site $833 P$-wave measurements, and the crustal structure is computed to fit the whole set of observed arrival times for all the North Aoba Basin lines (E10-7, E10-8, E13-4, and E13-5). 

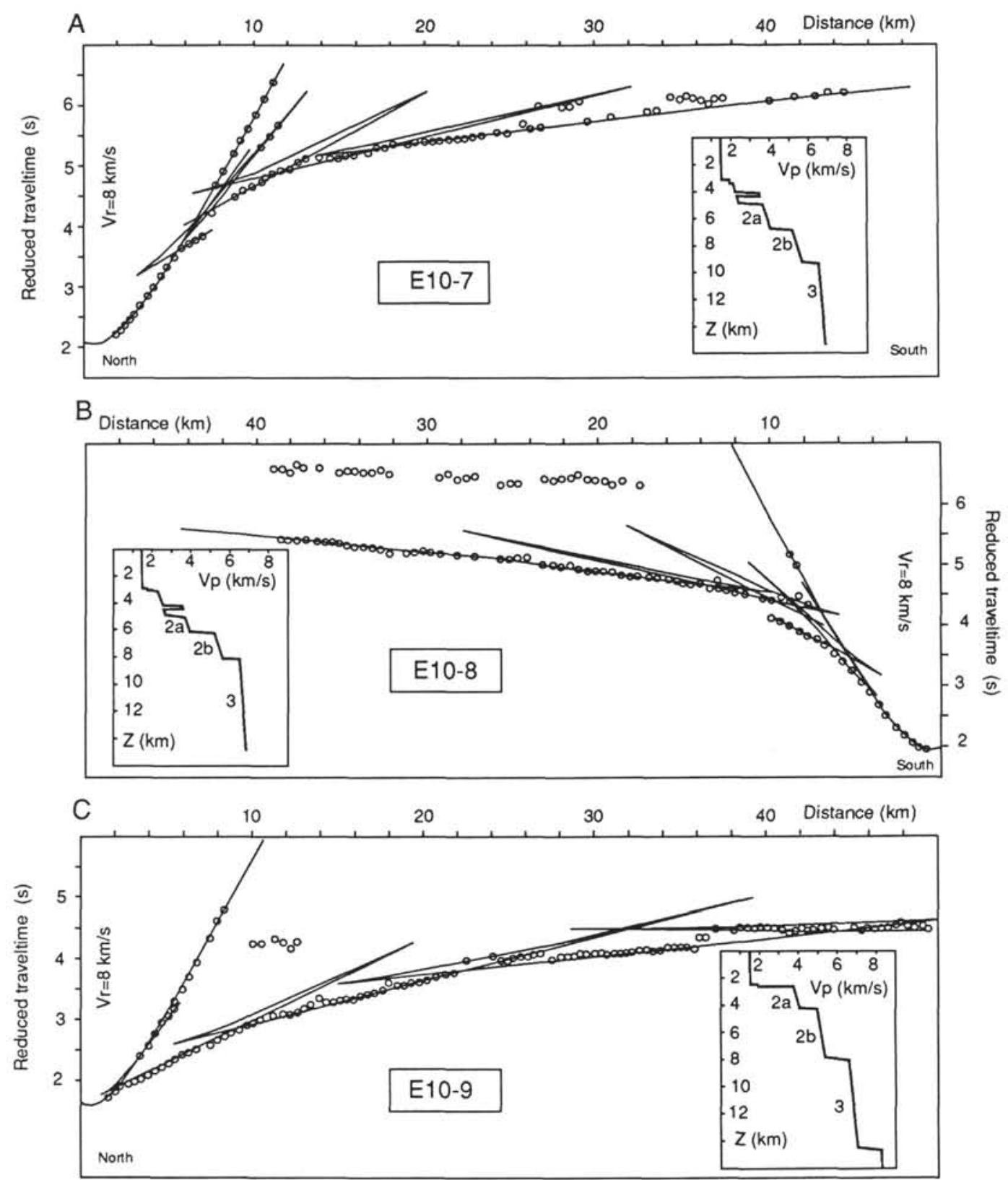

D

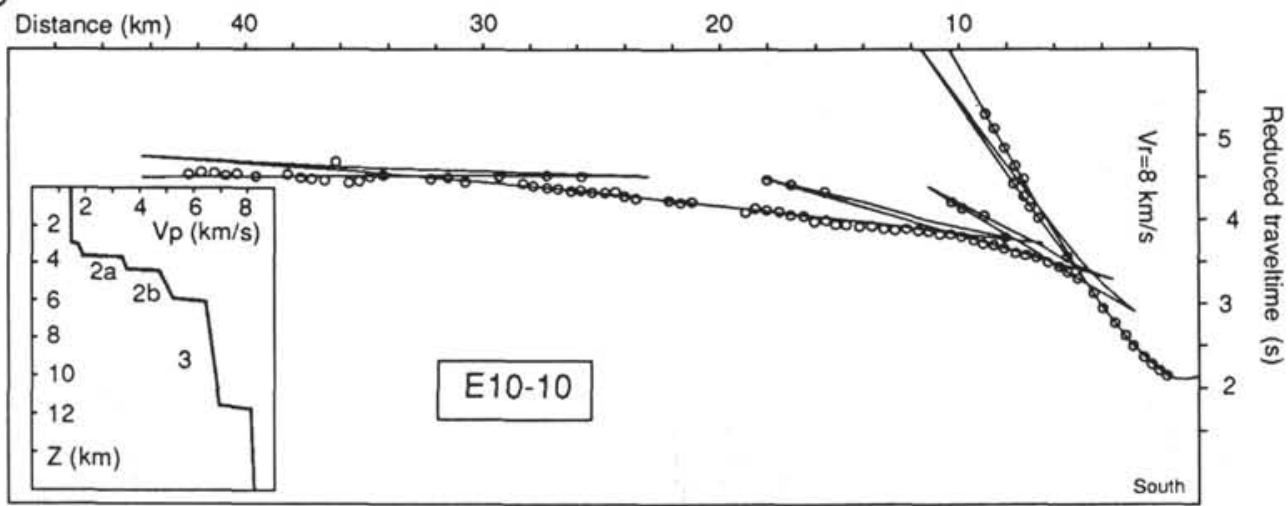

Figure 5. One dimensional velocity vs. depth models obtained from line E10-7 (A) and E10-8 (B) in the North Aoba Basin and lines E10-9 (C) and E10-10 (D) in the North Fiji Basin. Open circles denote the traveltime picks corrected for topographic effects; solid lines indicate the computed traveltimes. Traveltimes are reduced using a reducing velocity of $8 \mathrm{~km} \mathrm{~s}^{-1}$. For each line the inset shows the velocity vs. depth model used to compute traveltimes. Note that the Moho discontinuity is constrained by mantle arrival only for the North Fiji Basin lines. 


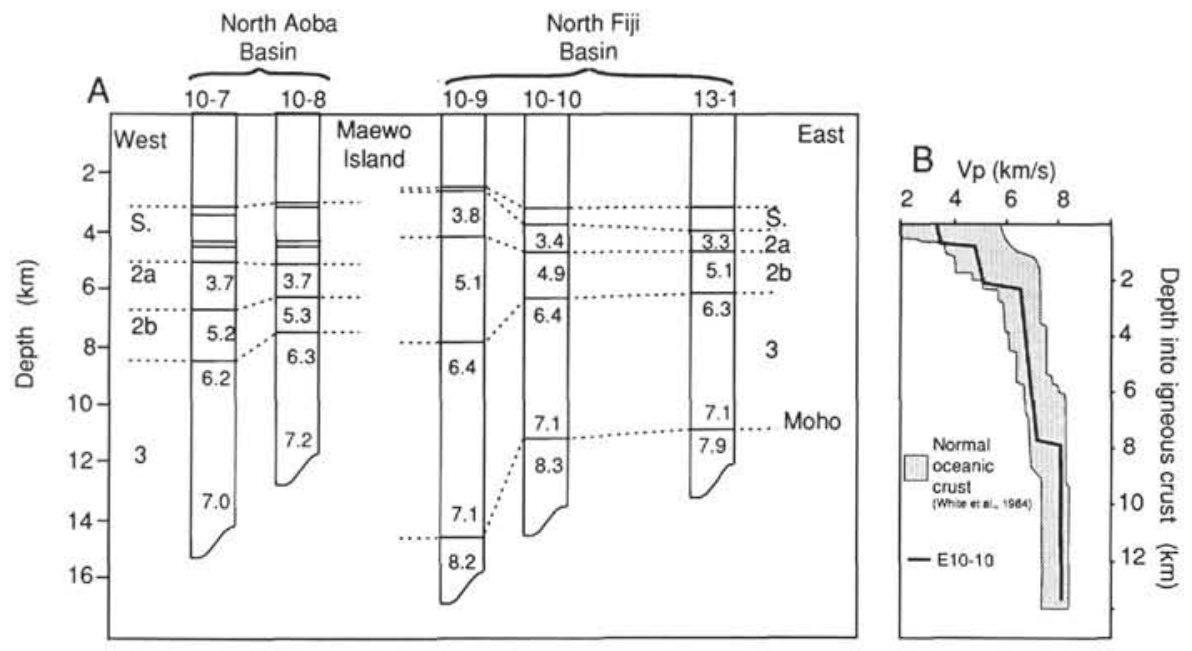

Figure 6. A. Correlation between 1D models: $\mathrm{S}=$ sediments; $2 \mathrm{a}=$ oceanic Layer $2 \mathrm{a} ; 2 \mathrm{~b}=$ oceanic Layer $2 \mathrm{~b} ; 3$ = oceanic Layer 3 . Columns are presented from west to east (except line 13-1, which was projected from $200 \mathrm{~km}$ north of line E10-10) but there is no horizontal scale. Line 13-1 is used as a reference line for the western border of the North Fiji Basin (Sage and Charvis, 1991). B. The velocity vs. depth model obtained for the North Fiji Basin along line E10-10 (solid line) is superimposed on standard oceanic crust velocity vs. depth bounds (in light gray) from White et al. (1984) obtained for the Atlantic crust.

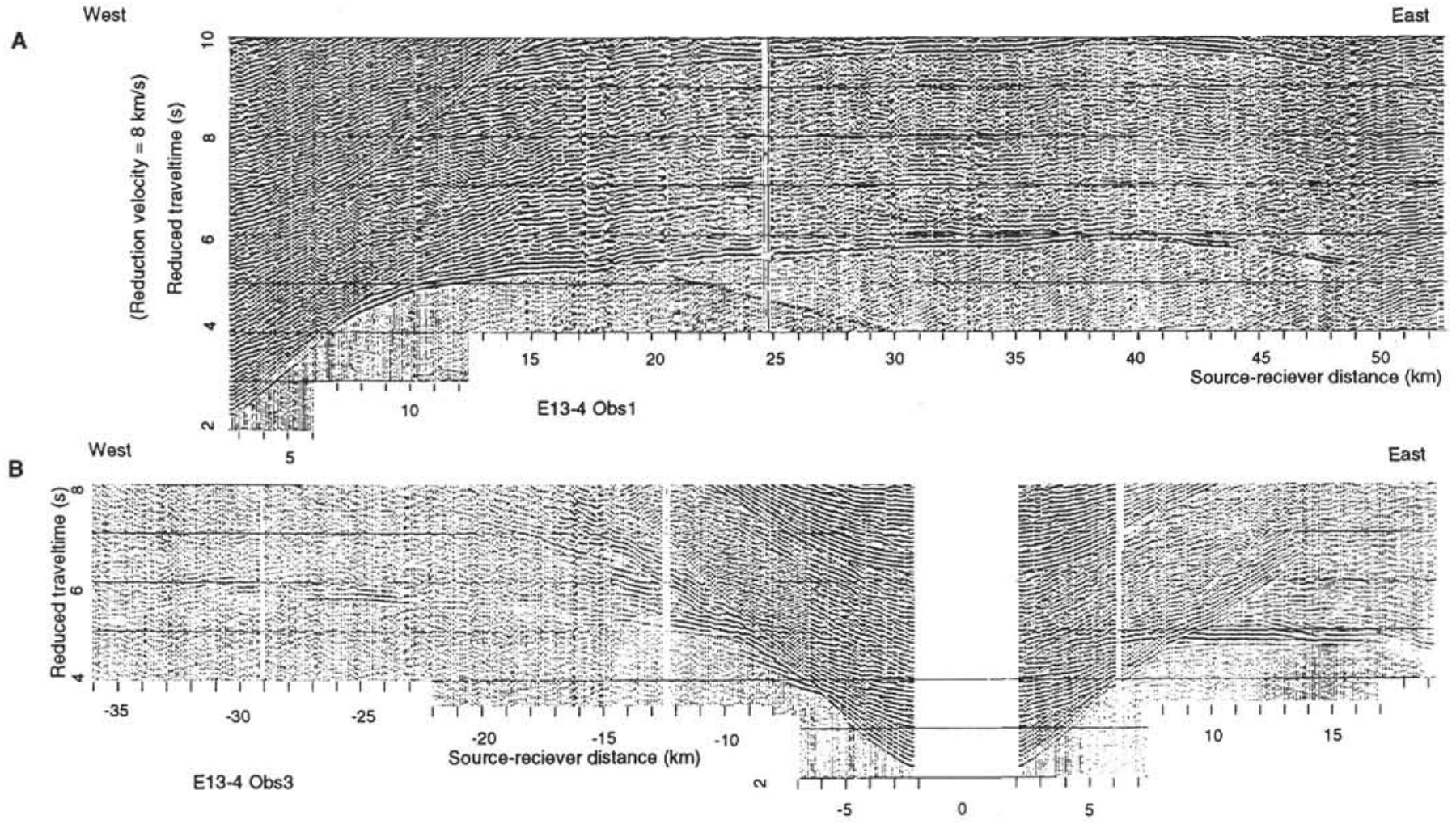

Figure 7. Record sections obtained for E13-4 seismic refraction line (A) OBS1, and (B) OBS3. A linear gain with distance and with time was applied to the data. The data are band-pass filtered between 5 and $15 \mathrm{~Hz}$. The reducing velocity is $8 \mathrm{~km} \mathrm{~s}^{-1}$. Some gaps in data are due to cassette rewinding during the experiment (between 24.5 and $25.0 \mathrm{~km}$; Fig. 7A) or due to the ship's track that did not pass exactly over the OBS (between $-2 \mathrm{~km}$ and $2 \mathrm{~km}$; Fig. 7B). Hardware dependent coherent noise are observed from 21 to $30 \mathrm{~km}$ and from 5 to $4 \mathrm{~s}$ on Figure 7A. Very high apparent velocities, observed for distances greater than $40 \mathrm{~km}$ on record section from OBS1 (this figure) and OBS4 (next figure) along line E13-4, are due to topographic effects of the western and eastern flanks of the basin. 


\section{A West}

East

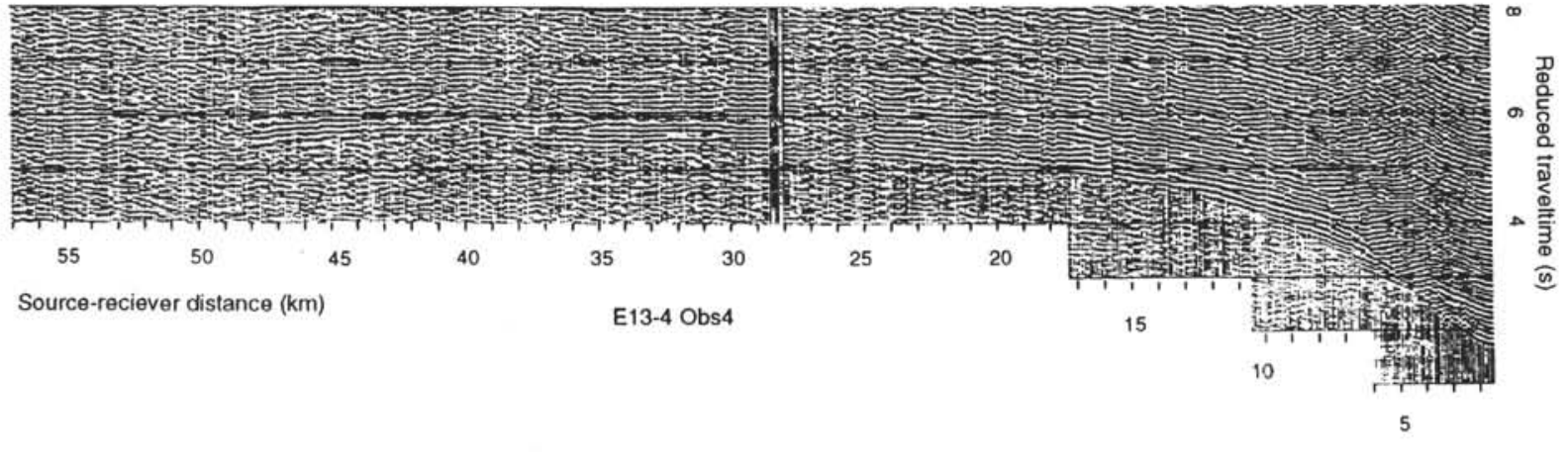

B South

North

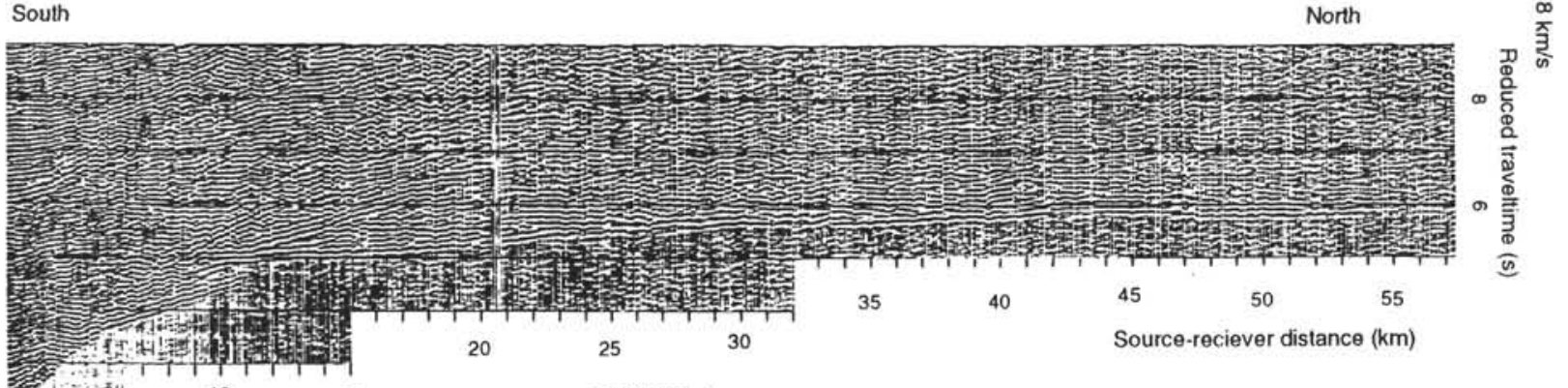

E13-5 Obs 1

Figure 8. Record sections for (A) line E13-4, OBS4, and (B) line E13-5, OBS1. Same as Figure 7.

\section{Sedimentary Structure of the North Aoba Basin}

All the record sections of the North Aoba Basin exhibit shadow zones between 7 and $10 \mathrm{~km}$ range except for the record section from OBS1 of line E13-4 located on the western border of the North Aoba Basin (Figs. 2 and 7). Shadow zones are related to a decrease of the velocity with depth, induced by a high-velocity layer. These zones (velocity reversals) introduce ambiguities in seismic refraction interpretation because the velocity structure within the low-velocity channel is not directly defined from seismic refraction data.

We tentatively combined the results from seismic refraction data with the $P$-wave measurements from the nearest site (i.e., Site 833 ; Collot, Greene, Stokking, et al., 1992), which is located very close to the eastern end of line E13-4 (Fig. 2). The velocity data for Site 833 were two-way traveltime below seafloor converted (in milliseconds) using measured velocities and thicknesses (Fig. 9). Two sets of data were used: data from recovered sediments (0 to $300 \mathrm{mstwt}$ ) and from downhole sonic logs ( 300 to $720 \mathrm{mstwt}$ ). Data were averaged to minimize small-scale variations. The lithostratigraphic succession at site 833 is divided into five lithostratigraphic units (noted with roman numerals in Table 1). Unit I, $84 \mathrm{~m}$ thick ( 0 to $110 \mathrm{mstwt}$, Fig. 9 ), is composed of unlithified volcanic silts. Unit II, $298 \mathrm{~m}$ thick (110 to 390 mstwt, Fig. 9), is composed of volcanic siltstones and sandstones. Both units are characterized by an increase of $P$-wave velocity with depth from 1.5 to $2.1 \mathrm{~km} \mathrm{~s}^{-1}$. Unit III is $202 \mathrm{~m}$ thick ( 390 to $535 \mathrm{mstwt}$, Fig. 9) and displays coarse-grained volcanic sandstones and finegrained basaltic breccias. Its $P$-wave average velocity is much higher $\left(3.2 \mathrm{~km} \mathrm{~s}^{-1}\right.$ ) than that of Units I and II. Unit IV, $252 \mathrm{~m}$ thick (535 to 720 mstwt, Fig. 9), begins with the disappearance of basaltic breccias and is dominated by coarse volcanic sandstones. Its measured $P$-wave velocity decreases from 3.2 (average $P$-wave velocity of Unit III) to $2.5 \mathrm{~km} \mathrm{~s}^{-1}$. Finally, the last lithostratigraphic unit, Unit V, consists of volcano-sedimentary rocks interbedded with basaltic sills that appear at $830 \mathrm{mbsf}(720 \mathrm{mstwt})$. The presence of interbedded basaltic sills causes a strong increase of the mean $P$-wave velocity of Unit V to

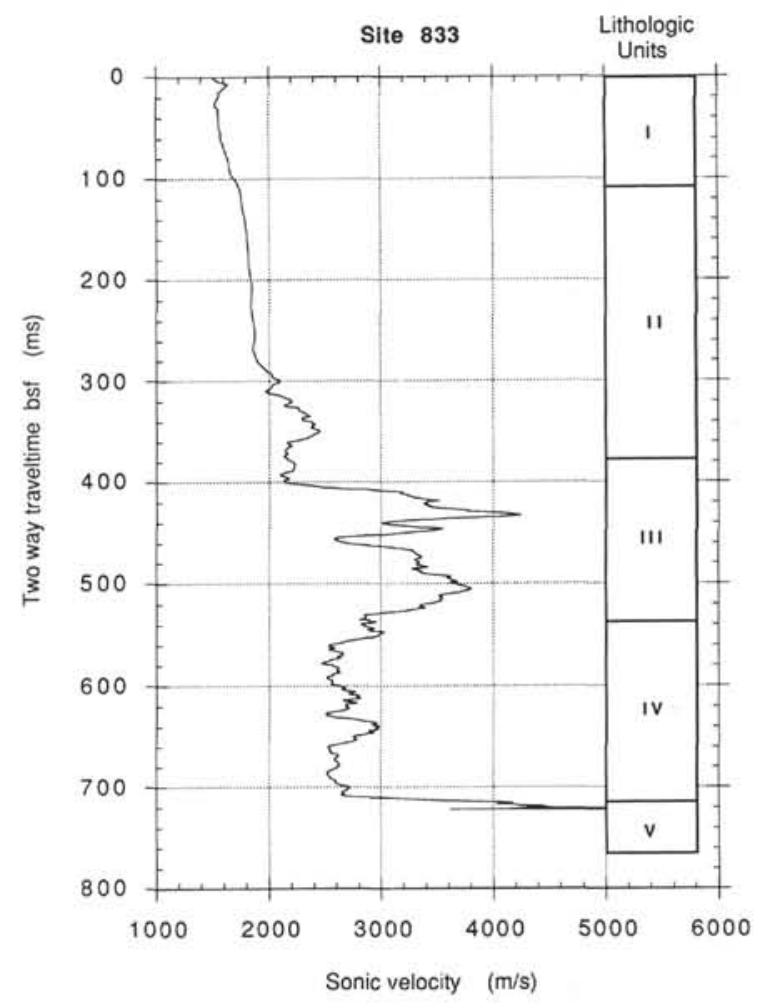

Figure 9. Site $833 P$-wave sonic velocity measurements vs. milliseconds two-way traveltime below seafloor. Data between 0 and $300 \mathrm{~ms}$ are taken from core sample $P$-wave velocity analyses. Data below $300 \mathrm{~ms}$ are downhole logging data. Data were smoothed to minimize small-scale variations. Lithologic units as determined from samples observations are shown on the right side of the figure (after Collot, Greene, Stokking, et al., 1992). 
Table 1. Comparison of velocity and thickness of the lithostratigraphic units from Site 833 with those obtained from seismic refraction line E13-4, OBS3.

\begin{tabular}{|c|c|c|c|c|c|c|}
\hline $\begin{array}{c}\text { Lithostratigraphic } \\
\text { unit }\end{array}$ & Lithostratigraphy & Age & $\begin{array}{l}\text { Velocity* } \\
\left(\mathrm{km} \mathrm{s}^{-1}\right)\end{array}$ & $\begin{array}{l}\text { Thickness* } \\
\text { (m) }\end{array}$ & $\begin{array}{l}\text { Velocity } \\
\left(\mathrm{km} \mathrm{s}^{-1}\right)\end{array}$ & $\begin{array}{l}\text { Thickness** } \\
\text { (m) }\end{array}$ \\
\hline I & $\begin{array}{l}\text { Unlithified volcanic silts, } \\
\text { volcanic ash }\end{array}$ & $\begin{array}{l}\text { late Pleistocene } \\
\text { to Holocene }\end{array}$ & $1.5-1.7$ & 84 & $1.5-1.9$ & $500^{* * * *}$ \\
\hline II & Volcanic silts & $\begin{array}{l}\text { Pleistocene } \\
\text { to Holocene }\end{array}$ & $1.7-2.2$ & 298 & $2.2-2.3$ & 600 \\
\hline III & $\begin{array}{l}\text { Coarse-grained } \\
\text { volcanic sandstones, } \\
\text { basaltic breccias }\end{array}$ & late Pliocene & $2.8-4.2$ & 200 & $3.0-3.3$ & 200 \\
\hline IV & $\begin{array}{l}\text { Volcanic siltstones, } \\
\text { nannofossil chalk }\end{array}$ & Pliocene & 2.5 & 252 & $?$ & 200 \\
\hline v & $\begin{array}{l}\text { Sedimentary rocks } \\
\text { interbedded with } \\
\text { basaltic sills }\end{array}$ & early Pliocene & 4.0 & 170 & 4.0 & 200 \\
\hline
\end{tabular}

Note: * Site 833; ** seismic refraction, E13-4 (OBS3); *** from Holmes (1988).

values as high as $4.1 \mathrm{~km} \mathrm{~s}^{-1}$. In order to compare ODP data with seismic refraction data, we deconvolved the close range part of the record section from OBS3 along line E13-4 to enhance precritical reflections. We used OBS3 record section rather than OBS4 record section, that is located near Site 833, because it exhibits the strongest precritical reflections, as it is located in the central part of the North Aoba Basin where the sedimentary layers are almost flat, horizontal and thicker than in the Site 833 area (Fig. 10). This close-range deconvolved record section exhibits three main reflections, designated R1, R2, and R3, which can be correlated at zero offset with reflectors observed along the MCS line Lee-21. Note a difference of $2.1 \mathrm{~s}$ at zero-offset between the time scales of the refraction record section and that of the MCS line. This difference is observed because the MCS records two-way traveltime, whereas the OBS records one-way traveltime for the direct water-wave. Site 833 has been projected along a north-south trend onto the MCS line Lee-21. The lithostratigraphic units defined at Site 833 (Collot, Greene, Stokking, et al., 1992) can be correlated with strong reflectors (Fisher et al., this volume). These reflectors extend throughout the MCS line Lee-21 toward the central part of the basin, where they can be correlated with reflected arrivals from OBS3 line E13-4. This correlation ties the lithostratigraphic units defined at Site 833 with the seismic refraction record section.

A one-dimensional velocity vs. depth model, computed using refracted and reflected seismic arrival times, exhibits two high velocity layers (HVL), the upper layer and the lower layer (HVL1 and HVL2, respectively; Fig. 11), interlayered within the sedimentary series. Those high velocity layers induce low velocity zones (LVL1 and LVL2; Fig. 11) in the velocity vs. depth profile.

Rock velocities obtained from downhole measurements and velocities computed from seismic refraction data show minor differences (Table 1). These differences can be related either to instrumental uncertainties or to lateral variations along line Lee- 21 . The sonic log used a $12-\mathrm{kHz}$ frequency signal whereas the frequency of the seismic refraction signal was around $12 \mathrm{~Hz}$. Furthermore, whereas logging velocities are measured only locally, seismic refraction velocities are integrated over several kilometers, corresponding to the horizontal propagation of the waves. Thus the differences between seismic refraction velocities and logging velocities may be partly due to technical artifacts. The thicknesses computed from seismic refraction data are larger for Units I and II than those observed at Site 833. This result is consistent with the thickening of these sedimentary units toward the central part of the North Aoba Basin observed along line Lee-21 (Fig. 10). The upper high velocity layer, designated HVL1, (Fig. 11) is correlated with a layer composed of volcanic breccias and coarse-grained sediments (Unit III, Table 1). This layer has about the same thickness $(200 \mathrm{~m})$ on the eastern flank of the basin (Site 833) and in the center of the basin (OBS3, line E13-4). Unit IV corresponds to the first low velocity layer, designated LVL1 (Fig. 11), and we use its average velocity as determined from ODP (Table 1), in the velocity vs. depth profile. The lower high velocity layer HVL2 (Fig. 11) is correlated with the volcanic sill complex reached at Site 833 (Unit V; Table 1). This high velocity layer can be recognized using data recorded on all but the westernmost one (OBS1, line E13-4; Fig. 2). At each location the lower high velocity layer has comparable velocity and thickness. Immediately below HVL2, the underlying low velocity layer LVL2 (Fig. 11) exhibits internal reflectors on the MCS line Lee-21 (Fig. 10) (below 5.6 stwt in the left part of the line), suggesting that layer LVL2 is still a sedimentary layer. In our seismic refraction data modeling, we assumed that LVL2 has a velocity of lithified sediments, ranging from 3.1 at the top to $3.4 \mathrm{~km} \mathrm{~s}^{-1}$ at the bottom. Based on this assumption the thickness of LVL2 is $1.8 \mathrm{~km}$.

Based on seismic refraction results of line E13-4, the total thickness of the sedimentary fill of the North Aoba Basin is at least $3.5 \mathrm{~km}$ in the central part of the basin. The lower HVL2 observed in the sedimentary series of the North Aoba Basin can be interpreted as a volcanic sill because the $P$-wave velocity $\left(V_{p}=4 \mathrm{~km} \mathrm{~s}^{-1}\right)$ of this layer falls within the range of $P$-wave velocity observed in volcanic flows, the lateral extension of this thin layer is compatible with a sill, and Site 833 reached a sill complex, which can be reasonably correlated with the high velocity layer observed on seismic refraction data throughout the basin. This volcanic sill appears to have a large extension throughout the basin as it induces shadow zones on all but the westernmost OBS of line E13-4.

The seismic refraction data of lines E13-4 and E13-5 can be compared with the 24-channel seismic line M-1031 (Fig. 2), trending northnorthwest-south-southeast. This section (Figs. 12A and B) shows the well layered late Pliocene-Pleistocene sedimentary deposits overlying the older (lower Miocene-Pliocene) strata, characterized by discontinuous high amplitude-low frequency reflectors (Gérard, 1993). In the central part of the basin, the high amplitude-low frequency reflectors are affected by faults. This faulted zone is overlain by rocks characterized by a chaotic seismic facies. On the northern part of the line, the high amplitude-low frequency reflectors are also present. Site 832, located on the northern part of the line (Fig. 12A) reached a 76-m-thick level near $700 \mathrm{mbsf}$ that is characterized by basaltic breccias interbedded with volcanic sandstones, with a mean $P$-wave velocity of 3.8 $\mathrm{km} \mathrm{s}^{-1}$ (Unit IV; Collot, Greene, Stokking, et al., 1992). This lithostratigraphic unit is marked as a high velocity layer in the Site 832 


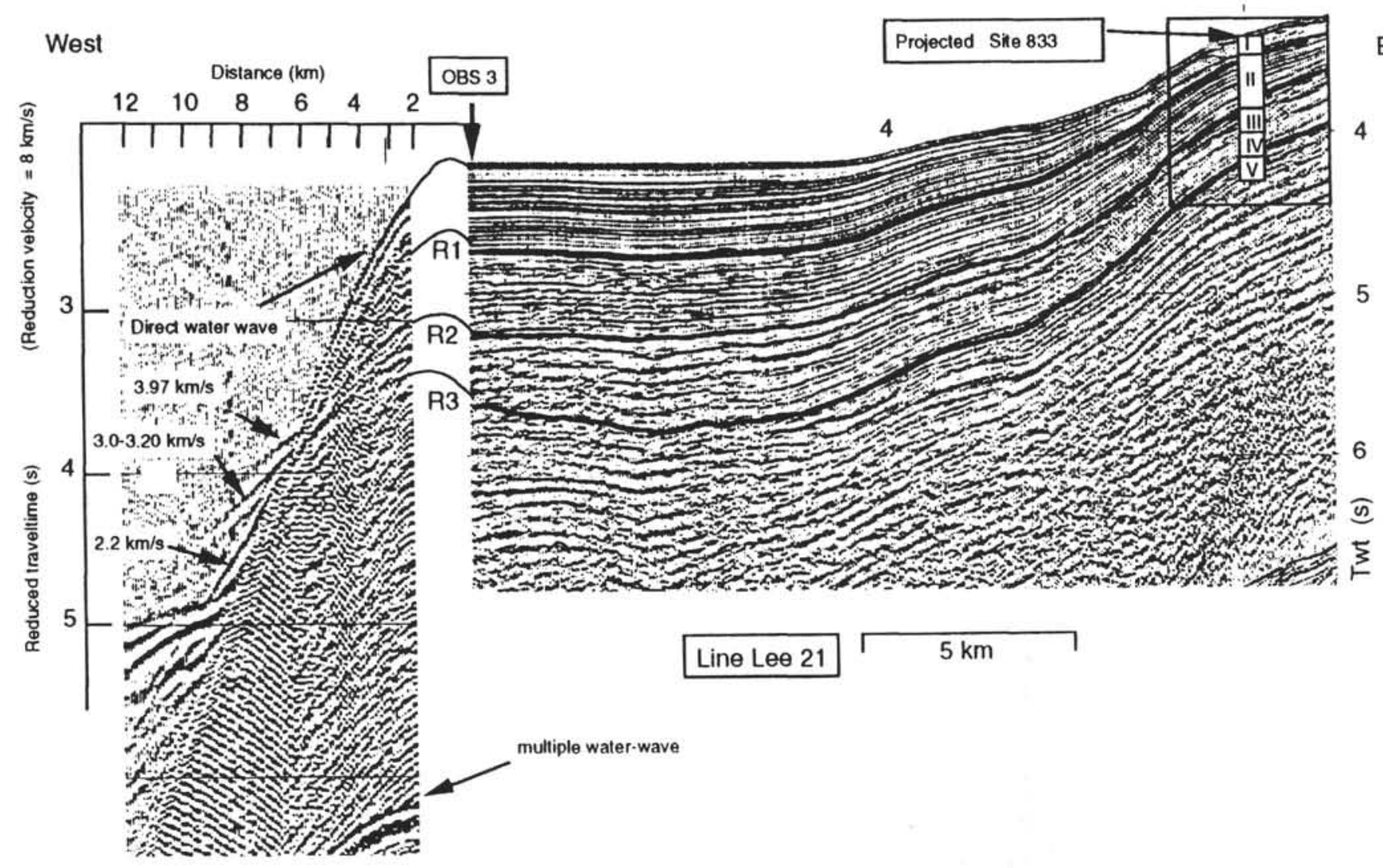

Line E13- 4 Obs 3
(deconvolved)

Figure 10. On the left, a deconvolved seismic refraction record section from line E13-4 OBS3 shows wide angle reflections (R1, R2, R3) and corresponding refracted arrivals. On the right, part of the Lee-21 MCS line, extending between the OBS3 (line E13-4) and Site 833, illustrates the correlation between reflections as recorded on the OBS, reflectors from the MCS data, and the lithologic units as defined from Site 833. Note that the correspondence between the reflections as observed on the refraction line and from the MCS line has an offset of $2.1 \mathrm{~s}$ (i.e., R3 is at $3.5 \mathrm{~s}$ on the refraction record section and at $5.6 \mathrm{~s}$ on the MCS line; see text for explanations).

sonic log. The expected two-way traveltime of the previously defined HVL1 and HVL2 are respectively $5.3 \mathrm{~s}$ and $5.6 \mathrm{~s}$ below the intersection between lines E13-4 and M-1031 (Fig. 12A) where they can be connected with strong reflectors and followed throughout the basin. Along the northern part of line M-1031, HVL1 can be correlated with the level of basaltic breccias recovered from 700 mbsf at Site 832.

Along a north-south section, on seismic refraction line E13-5 OBS1 (Fig. 13), an offset on observed arrival times at distances ranging from 18 to $21 \mathrm{~km}$ away from the recording station can be modeled as a deep root of the high velocity layer with a velocity of around $4 \mathrm{~km} \mathrm{~s}^{-1}$, and extending vertically to the deepest layer down to $5.9 \mathrm{~km}$ depth (i.e., at the top of the Layer A). This root has a narrow horizontal extent, at least in the north-south direction, and can be interpreted as a dyke related with the sill identified as a high velocity layer.

\section{Crustal Structure of the North Aoba Basin}

Ray-tracing 2D models were computed to fit the whole set of observed arrival times along lines E13-4 (Figs. 14 and 15) and combined lines E13-5 and E10-7 (Fig. 13). The East-West model is also constrained by the data from line E10-8, which crosses line E13-4 between OBS3 and OBS1 (Fig. 16). The constraint on each model can be gauged qualitatively from the density of ray paths; the model is locally more accurate where the number of ray path is higher. The model along line E13-4 is the best constrained model because three OBSs were simultaneously deployed along the line (Fig. 16).

Across the North Aoba Basin, the igneous crust is composed of three layers, which are of relatively constant thickness along the northsouth E13-5 section (Fig. 13). The upper layer (A) is 0.6- to 1.0-kmthick with velocities ranging from 3.5 to $4.2 \mathrm{~km} \mathrm{~s}^{-1}$, the middle layer (B) is 1.0- to 2.0-km-thick with velocities ranging from 4.1 to $5.7 \mathrm{~km} \mathrm{~s}^{-1}$ and the lower layer $(\mathrm{C})$ is $5.4-$ to $6.2-\mathrm{km}$-thick with velocities ranging from 6.2 to $7.1 \mathrm{~km} \mathrm{~s}^{-1}$. The upper layer (A) can be interpreted either as the lowermost part of the sedimentary cover composed of highly lithified sediments, possibly enriched in volcanic elements, or as the uppermost layer of the igneous crust (layer 2a). Velocity and thickness of the middle (B) and lower (C) layers are characteristic of oceanic Layers $2 \mathrm{~b}$ and 3, respectively. Along E13-5 line, the Moho discontinuity deepens slightly toward the north from 14.5 to $16 \mathrm{~km}$ deep, and the igneous crust thickens from $8 \mathrm{~km}$ near the southern end of line E13-5 to $10 \mathrm{~km}$ near its northern end.

The east-west cross section of the North Aoba Basin (Figs. 14, 15, and 16) shows that the Moho discontinuity is slightly less than $15 \mathrm{~km}$ deep in the central part of the basin. The thickness of the igneous crust does not vary significantly along this section but the top of the igneous crust as well as the individual intra-crustal layers appear to rise on the eastern and western borders of the basin. Our data do not show clearly whether the Moho also becomes shallower near the eastern and the 


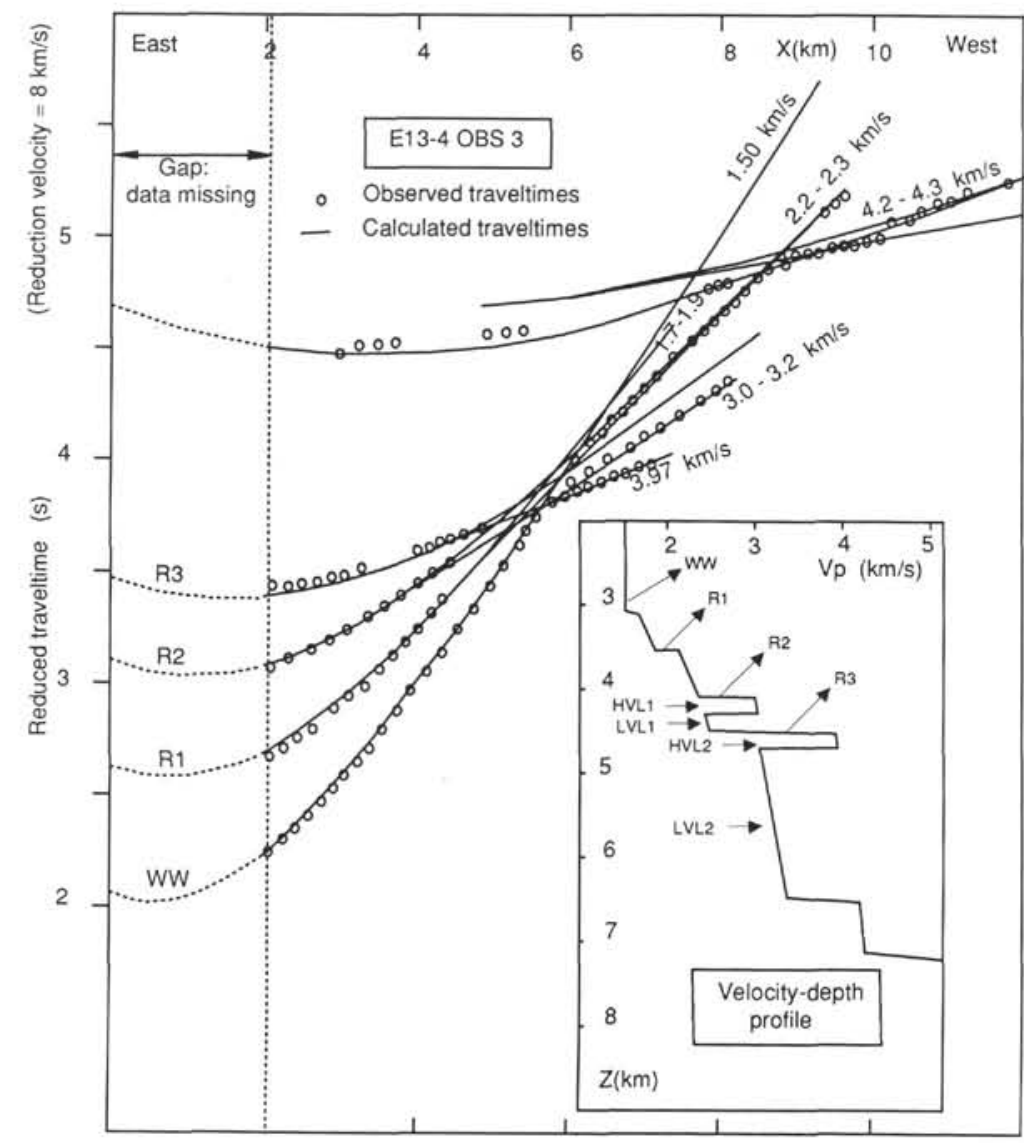

Figure 11. Observed traveltimes and calculated traveltimes; data for the 1D model shown as an inset. Data are from line E13-4, OBS3. The reducing velocity is $8 \mathrm{~km} \mathrm{~s}^{-1}$. HVL1 and HVL2 denote the high velocity layers, LVL1 and LVL2 the underlying low velocity layers.
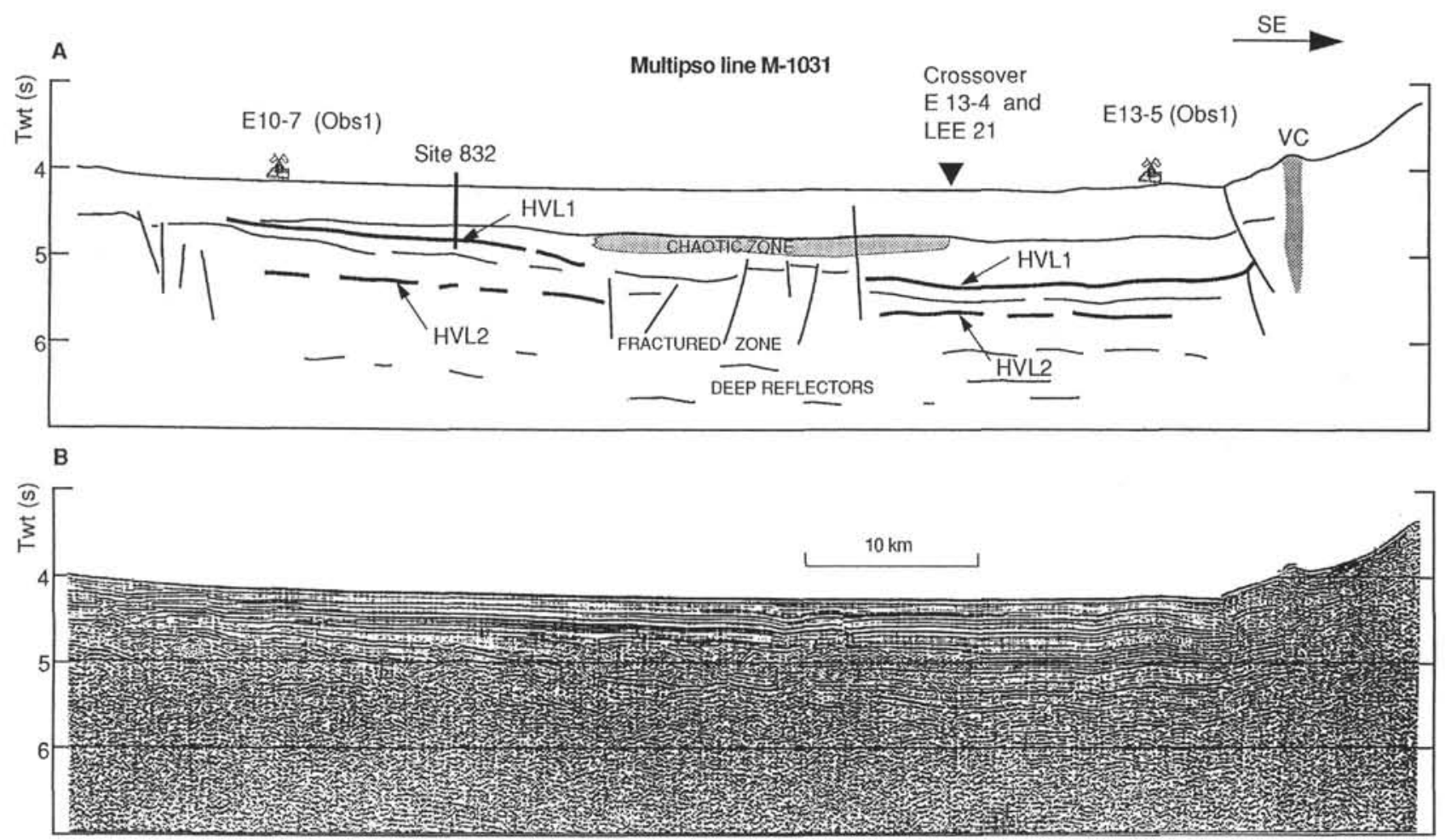

Figure 12. A. MCS M-1031 line drawing. The reflection at the top of the lower high velocity layer HVL1 and HVL2 are expected at $5.3 \mathrm{~s}$ and $5.6 \mathrm{~s}$, respectively, on the MCS line. We can follow these horizons almost throughout the basin in a north-south direction and the HVL1 can be connected with a high velocity layer of basaltic breccias sampled. B. MCS M-1031 line. 
North

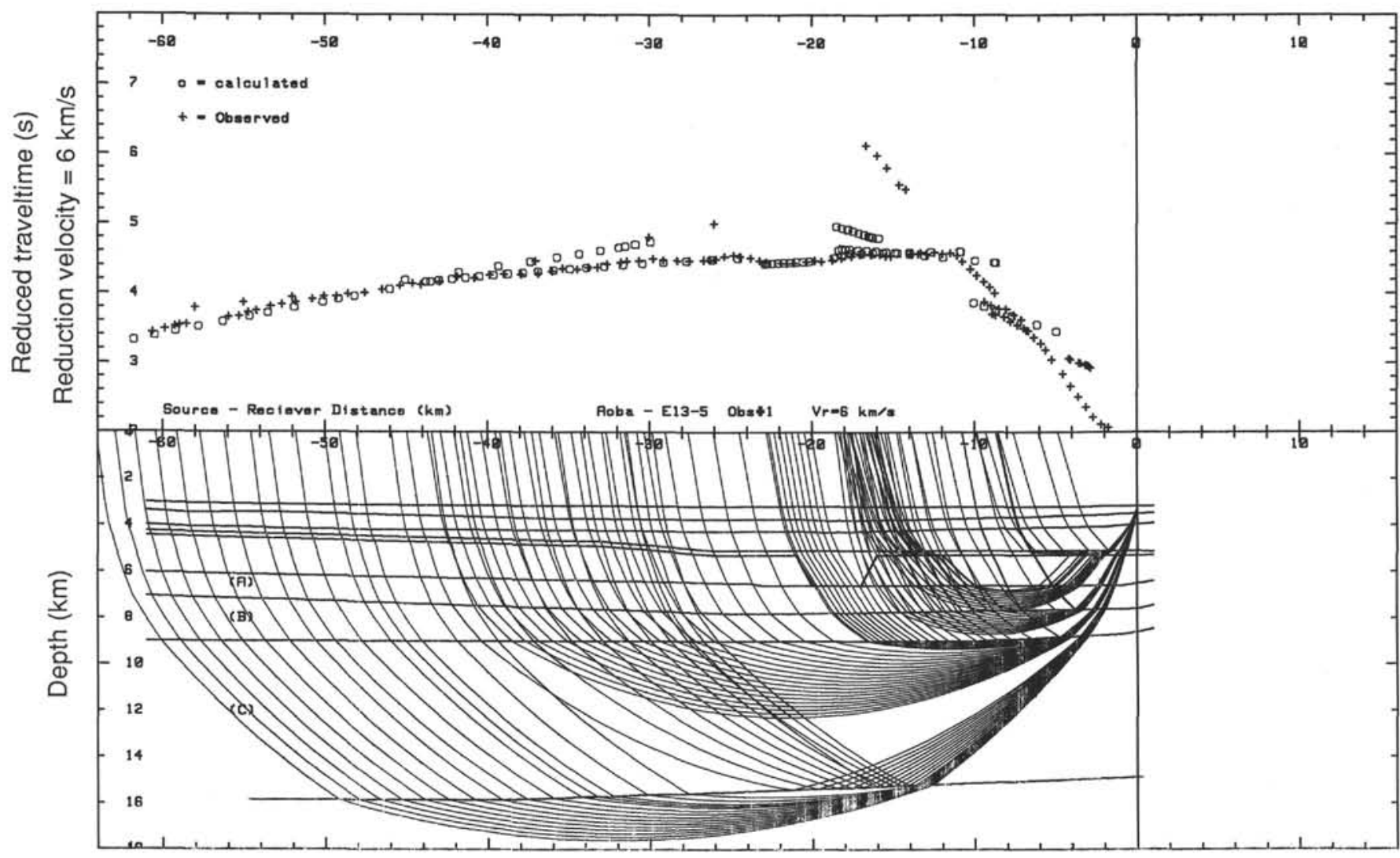

Figure 13. Example of ray tracing modeling for line E13-4, OBS1. Crosses are observed traveltimes, open circles are computed traveltimes. The reducing velocity is $8 \mathrm{~km} \mathrm{~s}^{-1}$. Ray paths used to compute the traveltimes are plotted in the model. For clarity, the LVL1 layer is not drawn in the superficial part of the models (Figs. 13,14 , and 15 ) and only rays having ray parameters greater than $0.25 \mathrm{~km} \mathrm{~s}^{-1}$ are presented.

western borders of the basin. The shape of the top of the igneous crust and of the intra-crustal layers is slightly asymmetric, with an eastern border apparently steeper than the western border (Fig. 16).

\section{DISCUSSION}

In this chapter we discuss the crustal structure of the North Aoba Basin and compare it to the crustal structures of the New Hebrides Island Arc, the North Fiji Basin, and other oceanic basins of the surrounding areas. These comparisons allow us to propose different hypotheses for the origin of the North Aoba Basin crust.

Previous crustal structure studies using a 2D gravity model of the North Aoba Basin along an east-west direction, together with a 1D model of seismic refraction data to constrain the shallow structure of the crust (Pontoise, 1984; Holmes, 1988), indicate a 12- to 13-km-thick crust (Collot and Fisher, 1988). Our study provides 2D velocity vs. depth models for the crust based on seismic refraction modeling of crustal and mantle arrivals along north-south (Fig. 13) and east-west trends (Figs. 14, 15, and 16). We obtained a total crustal thickness varying between $11 \mathrm{~km}$ (in the central part of the basin) and $13 \mathrm{~km}$ (in the northern part of the basin) consistent with the previous geophysical results.

We compare the crustal structure of the North Aoba Basin with those of the northern and southern segments of the New Hebrides Island Arc. The southern segment of the arc, south of Efate Island (Fig. 1), has a 26-km-thick crust with velocities ranging from 5.0 $\mathrm{km} \mathrm{s}^{-1}$ in the upper crust to $6.1-6.6 \mathrm{~km} \mathrm{~s}^{-1}$ in the lower crust (Ibrahim et al., 1980; Pontoise et al., 1982). In this area, the Moho is located at a depth of $28 \mathrm{~km}$. This result is based on long-range $(180 \mathrm{~km})$ seismic refraction profile using explosives as seismic sources and combined land-stations and OBSs. The northern segment of the arc, north of the Banks Islands (200 km north of line E13-4), has a crust that is estimated to be 15- to 16-km-thick (Sage and Charvis, 1991). This crust shows a 2 - to 4-km-thick upper layer with a velocity ranging from 4.5 to $4.9 \mathrm{~km} \mathrm{~s}^{-1}$ and a 9 - to $11-\mathrm{km}$-thick lower layer with a velocity increasing from $5.6 \mathrm{~km} \mathrm{~s}^{-1}$ at the top of the layer to $6.6 \mathrm{~km} \mathrm{~s}^{-1}$ at the bottom. This crustal model has been obtained using $2 \mathrm{D}$ ray tracing to fit the data observed on five OBSs along a line of closely spaced shots. Nevertheless the Moho depth is only constrained by mantle reflections (PmP). Along E13-5 line (Fig. 13), the Moho discontinuity deepens slightly toward the north from 14.5 to $16 \mathrm{~km}$ deep, and the igneous crust thickens from $8 \mathrm{~km}$ near the southern end of line E13-5 to $10 \mathrm{~km}$ near its northern end. This crustal thickening toward the northern part of the North Aoba Basin suggests that the northern part of the seismic refraction line E13-5 reaches a transition zone between the North Aoba Basin crust and the thicker island-arc crust. The differences between the northern and the southern segments of the island arc indicate that the crustal structure varies considerably along the New Hebrides Island Arc, but the igneous crust is generally thicker than $11 \mathrm{~km}$ and has velocities in the lowermost igneous crust between 6.0 and $6.6 \mathrm{~km} \mathrm{~s}^{-1}$. However, the igneous crust beneath the central part of the North Aoba Basin is only $8.5 \mathrm{~km}$ thick and the seismic velocities in the lower igneous crust $\left(6.2\right.$ to $\left.7.1 \mathrm{~km} \mathrm{~s}^{-1}\right)$ are $0.5 \mathrm{~km} \mathrm{~s}^{-1}$ higher than the velocity generally observed in the lowermost igneous part of island-arc crust. The reasons that the North Aoba Basin crust is thin compared to the crust of the northern and southern segments of the arc remains unclear. Nevertheless, the oceanic velocity vs. depth behavior of the North Aoba Basin crust suggests that little or no island-arc plutonism affected the crust. Island-arc plutonism and 
West

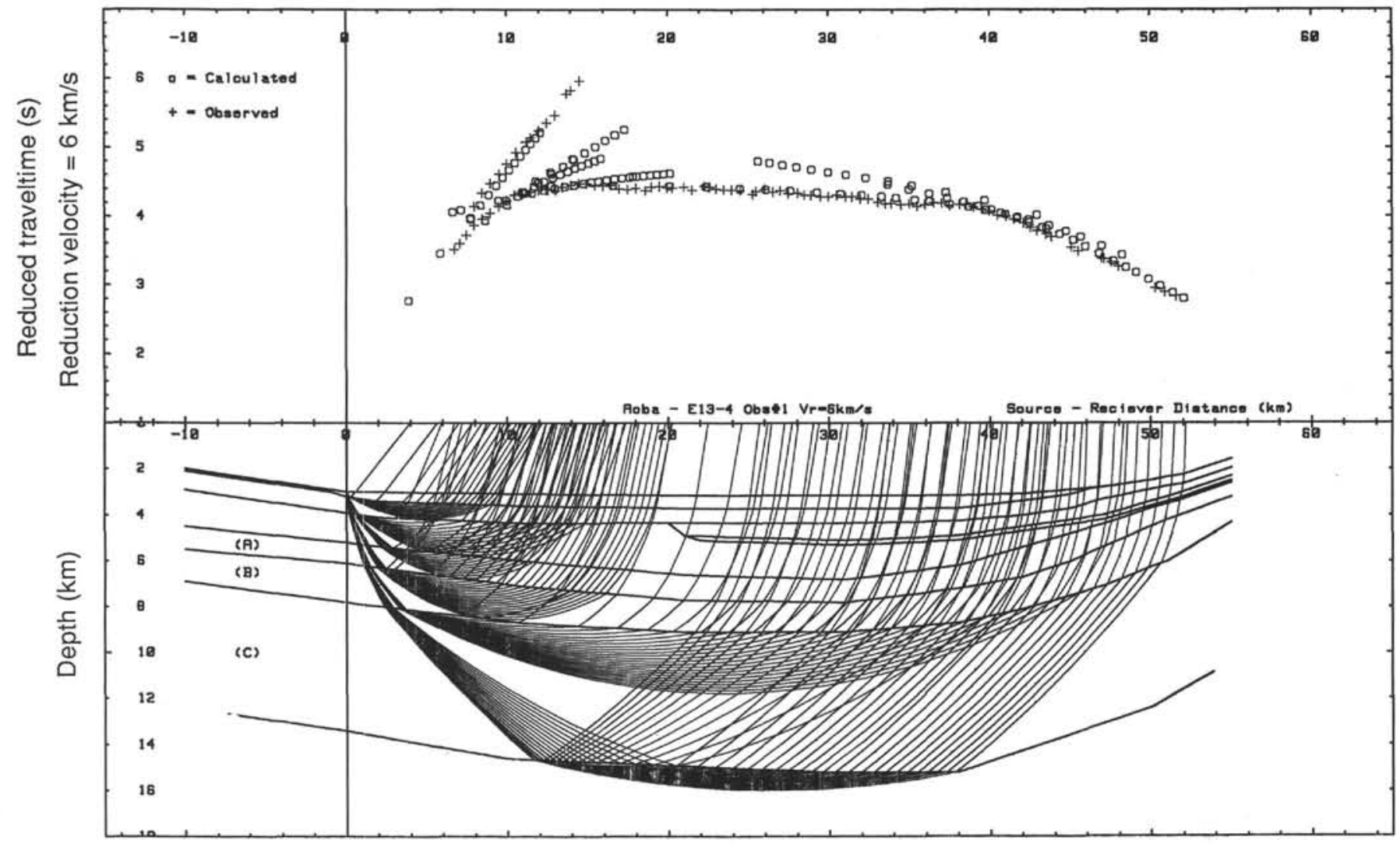

Figure 14. Same as Figure 13, line E13-4, OBS4.

volcanism may be important processes of island-arc crustal thickening. In the central segment of the New Hebrides Island-Arc, volcanic activity (Epi, Ambrym, Aoba, and Santa Maria islands) is concentrated along radiating faults associated with the collision of the d'Entrecasteaux Zone (Roca, 1978; Collot et al., 1985; Greene et al., 1988). This can partly explain the apparent lack of island-arc magmatism in the North Aoba Basin, which is located between the Aoba and the Santa Maria faults.

The 11- to 13-km-thick North Aoba Basin crust consists of a 3.5to $4.5-\mathrm{km}$-thick sedimentary cover overlying a $8.5-\mathrm{km}$-thick igneous crust. The igneous crust beneath the North Aoba Basin is similar to the oceanic crust of the North Fiji Basin along line E10-10 and its characteristics are within the range of those observed for standard oceanic crust (Fig. 17A; White et al., 1984). These results strongly suggest that the crust beneath the North Aoba Basin has an oceanic origin. We can also compare the crustal structure obtained beneath the North Aoba Basin with the crustal structure of the North Loyalty and the West Santo Basins, which are oceanic basins both located on the Australia-India subducting plate (Fig. 1). The igneous crusts of these two basins are $11.5 \mathrm{~km}$ and $12.7 \mathrm{~km}$ thick, respectively, and bear oceanic-type velocities (Pontoise et al., 1982; Pontoise and Tiffin, 1987). Nevertheless, the igneous crusts of the North Loyalty and West Santo basins are 4.0 to $4.5 \mathrm{~km}$ thicker than that of the North Aoba Basin (Fig. 17B). Moreover, thicknesses calculated for these basins were based on slope-intercept methods, and such methods are known to minimize the true thickness of the igneous crust by a factor of $14 \%$ to $19 \%$ (White et al., 1992). In this hypothesis the North Aoba Basin igneous crust is mostly thinner than that of North Loyalty and West Santo basins. These comparisons indicate that the North Aoba Basin is not part of the North Loyalty or West Santo Basins. No data on the crustal structure of the western Pacific crust are available, from which to compare with. We can only compare the velocity vs. depth function of the North Aoba Basin crust with the extreme values obtained for the 29- to 140-Ma Pacific crust (Fig. 17B) from a compilation of seismic refraction velocity vs. depth functions (White et al., 1992). From this compilation, it appears that the Pacific crust has a mean thickness of $6.87 \pm 0.29 \mathrm{~km}$ (White et al., 1992). If we consider that the observed Layer $2 \mathrm{a}$ is a sedimentary layer (its $3.0-4.4 \mathrm{~km} \mathrm{~s}^{-1}$ velocity is consistent with this interpretation), the velocity vs. depth function of the North Aoba Basin igneous crust fits within the velocity vs. depth range obtained for the Pacific crust, suggesting that the North Aoba Basin oceanic crust could be a fragment of the Pacific oceanic crust.

The thickness of the North Aoba Basin igneous crust is constant $(8.5 \mathrm{~km})$, at least in the central part of the basin where our data constrain the Moho depth (Figs. 13, 14, and 15). The layers of the igneous crust become progressively shallower on the eastern and western borders of the North Aoba Basin defining a syncline shape (Fig. 16). Normal faults affect the eastern (Greene and Johnson, 1988) and western flanks of the North Aoba Basin (Greene and Johnson, 1988; Fisher et al., 1988); however, those faults are located outside our seismic refraction line E13-4. From our data set, there is no evidence of faults with large offset affecting the deep crust in the central part of the North Aoba Basin. The above observations suggest that the North Aoba Basin, at least in its central part, is a large syncline of oceanic crust bent down between the Western Chain (Espiritu Santo Island) and the Eastern Chain (Maewo Island) rather than an asymmetric graben bounded by normal faults as suggested by Katz (1988) and Fisher et al. (1988). The syncline shape of the North Aoba Basin can be related to the observed recent uplifts of the Eastern and Western Chains, as a consequence of the collision of the d'Entrecasteaux Zone with the arc, and to the submergence of the Aoba Island (Collot et al., 1985; Taylor et al., 1987; Macfarlane et al., 1988; Taylor, 1992). 
West

East

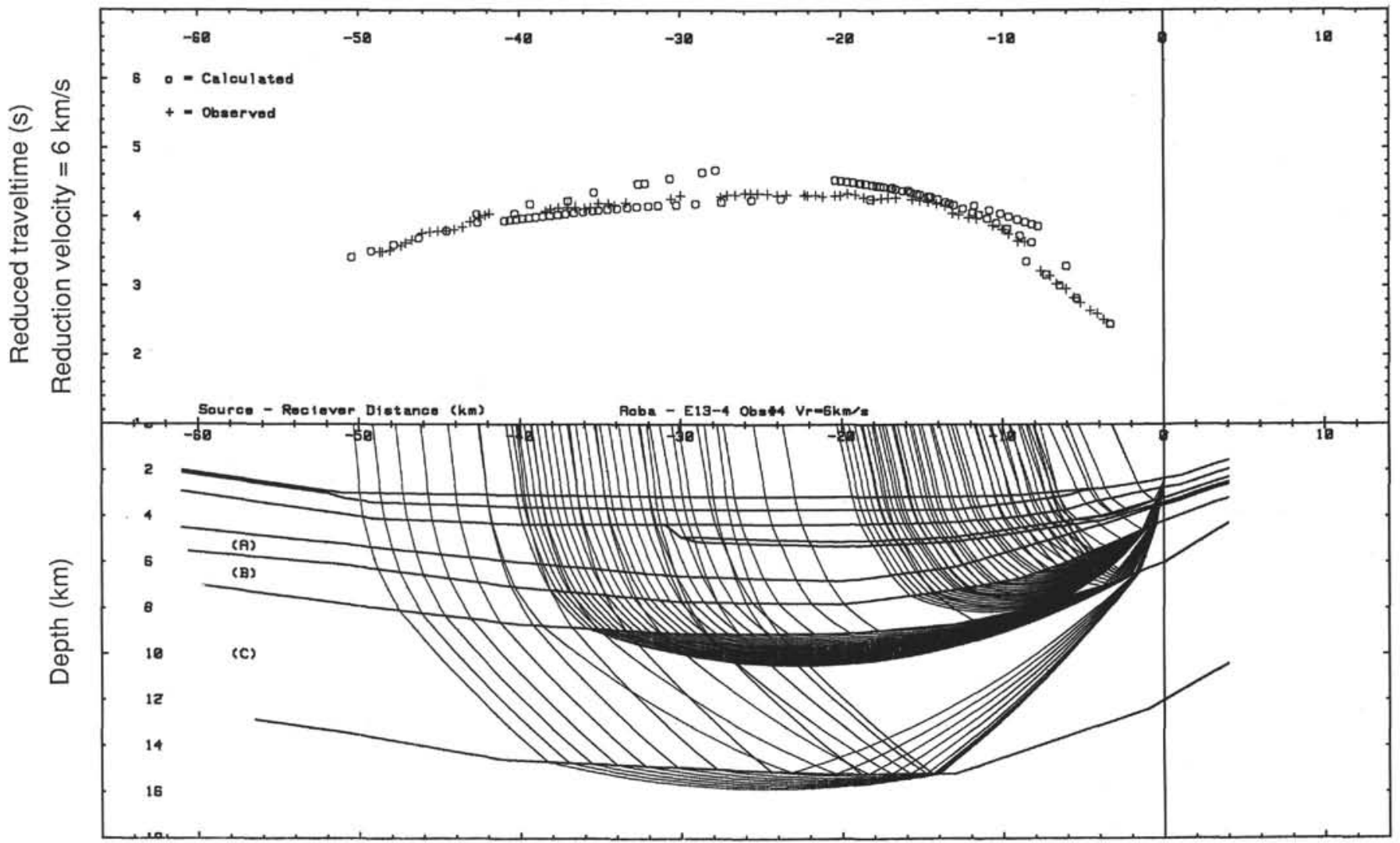

Figure 15. Same as Figure 13, line E13-5, OBS1.

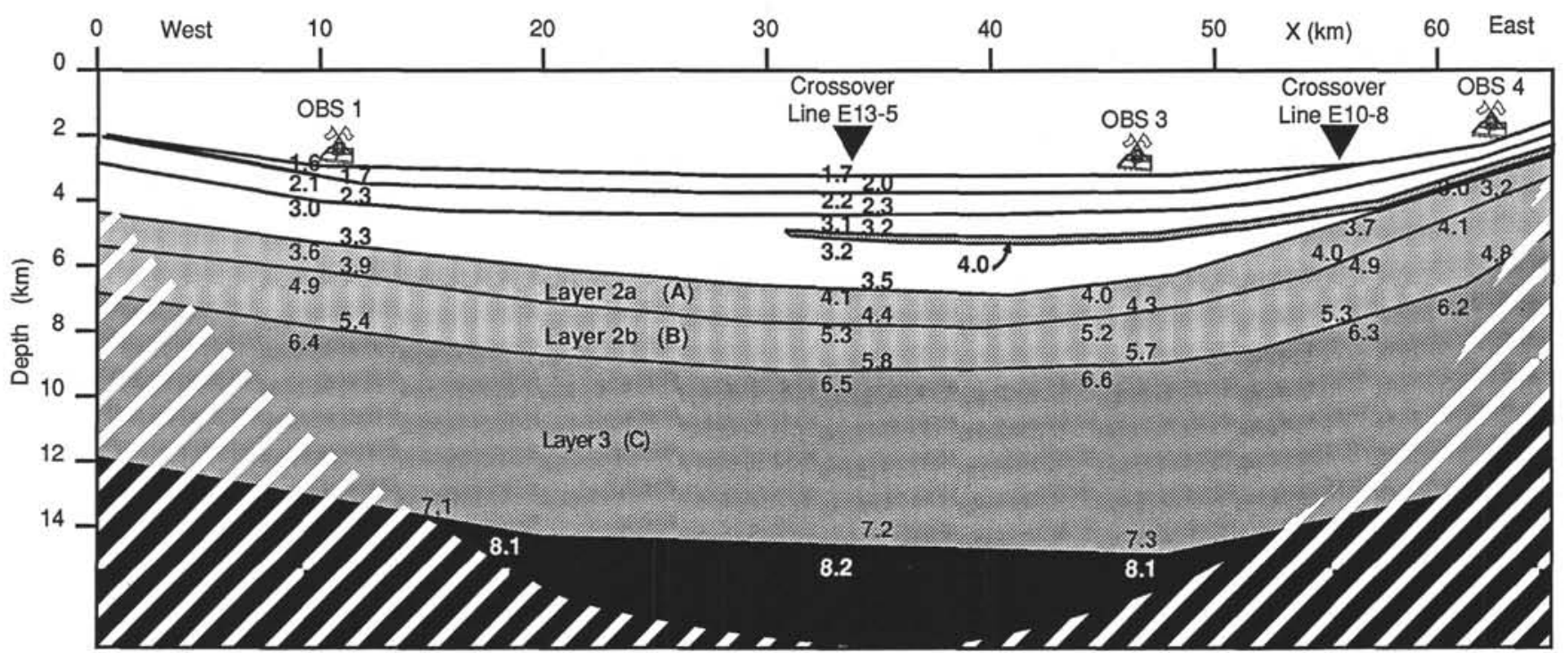

Figure 16. Synthetic model along line E13-4 corresponding to an east-west cross section in the North Aoba Basin. Velocities for the uppermost and lowermost part of each layer are in $\mathrm{km} \mathrm{s}^{-1}$. The sedimentary cover is in white, the upper crust (Layer 2a and 2b) in light gray, the lower crust (Layer 3) in dark gray and the upper mantle in black. Areas with white hachures are not constrained by our data. The locations of the 3 OBSs and the intersections with other seismic refraction lines are also indicated. 

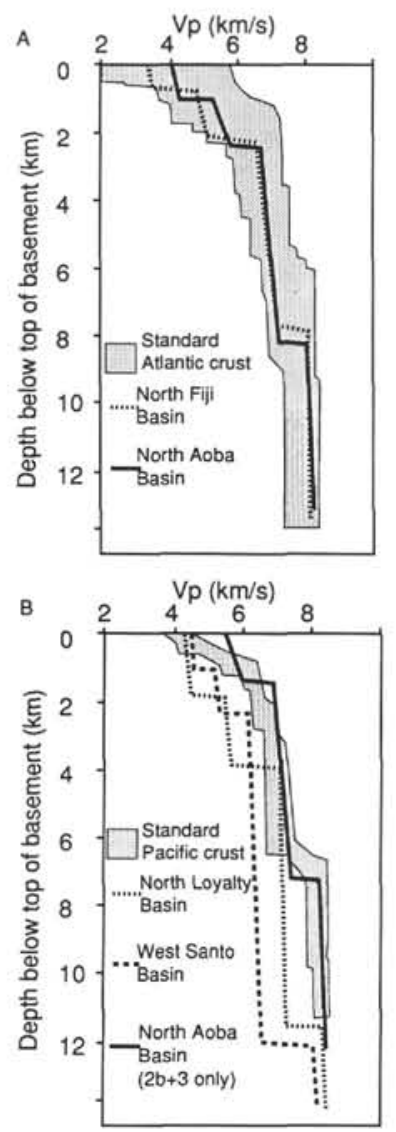

Figure 17.A. $P$-wave velocities depth below top of basement. Velocity vs. depth functions obtained for the North Aoba basin at the intersection between line E13-4 and E13-5 (solid line) and for the North Fiji Basin along line E10-10 (dotted line) are superimposed on standard oceanic crust velocity vs. depth bounds (in light gray) from White et al. (1984) for the Atlantic oceanic crust. B. Comparison of the velocity vs. depth function of the North Aoba Basin (solid line) with those of the West Santo Basin (dashed line) and the North Loyalty Basin (dotted line), both on the Australian Plate. In light gray is shown the compilation of velocity vs. depth profiles for the 29-140 Ma Pacific Crust (White et al., 1992). For the North Aoba Basin model, the layer with velocity from 3 to $4.4 \mathrm{~km} \mathrm{~s}^{-1}$ has been interpreted as sedimentary layer and only the Layers 2(b) and 3 are considered as parts of the igneous crust. In this case the North Aoba crustal model fits within the velocity vs. depth range for the Pacific model.

Focal mechanisms for shallow $(0-70 \mathrm{~km})$ earthquakes distributed along Maewo and Pentecost islands indicate thrust faulting (Fig. 4B; Collot et al., 1985; Louat and Pelletier, 1989). The very steep eastern flank of Maewo and Pentecost islands (Macfarlane et al., 1988) supports a west-dipping thrust zone. The observed thickening of the crust beneath line E10-9 compared to line E10-10 and beneath the Eastern Chain (Collot and Fisher, 1988) may be related to the tectonic duplication of the oceanic crust (Fig. 6).

\section{CONCLUSION}

The total thickness of the igneous crust in the western North Fiji Basin is $8 \mathrm{~km}$ beneath line E10-10. The velocity vs. depth profile for this line lies between extreme bounds for normal oceanic crust (Fig. 17A) as determined by White et al. (1984). The similarity between the E10-10 model and the models obtained for other different seismic refraction lines at different latitudes over the western part of the North Fiji Basin attests to the homogeneity of the 10 to $12 \mathrm{Ma}$ (Auzende et al., 1988; Monjaret, 1989) oceanic crust of the western North Fiji Basin.
The North Aoba Basin consists of a 7.5- to 8.5-km-thick piece of oceanic crust overlain by an average of $4 \mathrm{~km}$ of sediments, making a total crustal thickness of 11 to $13 \mathrm{~km}$. These sediments thin toward the eastern and western borders of the basin. A high velocity layer interpreted as a volcanic sill interlayered in the sedimentary series at $1.5 \mathrm{~km}$ below seafloor has a thickness of $200 \mathrm{~m}$. This volcanic sill is present all over the central and eastern parts of the North Aoba Basin (Figs. 12, 13, and 16).

The igneous crust beneath the North Aoba Basin is largely thinner than the crust of the southern and northern segments of the island-arc (Ibrahim et al., 1980; Pontoise et al., 1982; Sage and Charvis, 1991). Moreover, its seismic velocities in the lower igneous crust (6.2 to $7.1 \mathrm{~km} \mathrm{~s}^{-1}$ ) are $0.5 \mathrm{~km} \mathrm{~s}^{-1}$ higher than the ones generally observed in the northern and southern segments. The reasons the North Aoba Basin crust is thin compared to the crust of the northern and southern segments of the arc remains unclear. Nevertheless, the velocity vs. depth behavior of the North Aoba Basin crust suggests that little or no islandarc plutonism affected the crust.

The structure of the North Aoba Basin igneous crust is differentthat is, largely thinner-than that of the other oceanic basins located on the Australian Plate, precluding a common origin. However, the crustal structure of the North Aoba Basin is very similar to the crustal structure of the North Fiji Basin but can also be correlated with the crustal structure of the Pacific Plate, depending on the interpretation of the 3.0 to $4.4 \mathrm{~km} \mathrm{~s}^{-1}$ layer (Fig. 17A and 17B). These comparisons suggest two main hypotheses for the origin of the North Aoba Basin oceanic crustal fragment: the North Aoba Basin crust is a fragment of the Pacific crust trapped during the subduction of the Pacific Plate beneath the Australian Plate along the Vitiaz Trench; or alternatively, the North Aoba Basin crust could be a fragment of the North Fiji Basin crust. The main difference between these crusts is the thickness of the sedimentary cover, which is less than $0.5 \mathrm{~km}$ thick on the western border of the North Fiji Basin and averages $4 \mathrm{~km}$ in the central part of the North Aoba Basin.

Our seismic refraction data support the idea that, along an east-west cross section, the North Aoba Basin is as a large syncline of oceanic crust, at least in its central part, bent down between the Western (Espiritu Santo Island) and the Eastern Chains (Maewo Island), as suggested by Collot et al. (1985). The focal mechanisms of shallow earthquakes (Collot et al., 1985), the relative plate motions in the North Fiji Basin area (Louat and Pelletier, 1989), the existence of an asymmetric crustal root below Maewo (Collot and Fisher, 1988), and the crustal structure of the North Fiji Basin in the vicinity of Maewo Island (this study) are consistent with the North Aoba Basin crust overthrusting the North Fiji basin crust.

\section{ACKNOWLEDGMENTS}

This paper presents the results of ORSTOM geophysical cruises that could not be achieved without the support of IFREMER research vessels and participation of GENAVIR crew members. Special thanks to Yann Hello and Paul McPherson for successfully operating the TEXAS-ORSTOM Analog and Digital OBSs. Data from the EVA XIII experiment were processed at the University of Texas Institute for Geophysics. We wish to thank especially Dr. Y. Nakamura for his help during the processing of the data at the Institute. We also wish to thank Dr. J.-Y. Collot, Dr. H.G. Greene and anonymous reviewers for critically reviewing the original manuscript and offering helpful suggestions.

\section{REFERENCES ${ }^{*}$}

Auzende, J.-M., Lafoy, Y., and Marsset, B., 1988. Recent geodynamic evolution of the North Fiji Basin (Southwest Pacific). Geology, 16:925-929.

\footnotetext{
- Abbreviations for names of organizations and publications in ODP reference lists follow the style given in Chemical Abstracts Service Source Index (published by American Chemical Society).
} 
Carney, J.N., and Macfarlane, A., 1978. Lower to middle Miocene sediments on Maewo, New Hebrides, and their relevance to the development of the Outer Melanesian Arc system. Aust. Soc. Explor. Geophys. Bull., 9:123130.

Carney, J.N., Macfarlane, A., and Mallick, D.I.J., 1985. The Vanuatu island arc: an outline of the stratigraphy, structure, and petrology. In Nairn, A.E.M., Stehli, F.G., and Uyeda, S. (Eds.), The Ocean Basins and Margins (Vol. 7): New York (Plenum), 685-718.

Ceverny, V., Langer, J., and Psencik, I., 1974. Computation of geometrical spreading of seismic body waves in laterally inhomogeneous media with curved interfaces. Geophys. J., 38:9-19.

Collot, J.-Y., Daniel, J., and Burne, R.V., 1985. Recent tectonics associated with the subduction/collision of the d'Entrecasteaux zone in the central New Hebrides. Tectonophysics, 112:325-356.

Collot, J.-Y., and Fisher, M.A., 1988. Crustal structure, from gravity data, of a collision zone in the central New Hebrides Island Arc. In Greene, H.G. and Wong, F.L. (Eds.), Geology and Offshore Resources of Pacific Island Arcs-Vanuatu Region. Circum-Pac. Counc. Energy Miner. Resour., Earth Sci. Ser., 8:125-140.

Collot, J.-Y., Greene, H.G., Stokking, L., et al., 1991. Résultats préliminaire du Leg 134 de l'Ocean Drilling Program dans la zone de collision entre l'arc insulaire des Nouvelles-Hébrides et la zone d'Entrecasteaux. $C$. $R$. Acad. Sci. Ser. 2, 313:539-546.

Collot, J.-Y., Greene, H.G., Stokking, L.B., et al., 1992. Proc. ODP, Init. Repts. 134: College Station, TX (Ocean Drilling Program).

Daniel, J., Gérard, M., Mauffret, A., Boulanger, D., Cautin, B., Collot, J.-Y. Durand, J., Fisher, M., Greene, H.G., Michaux, P., Pelletier, B., Pezzimenti, A., Renard, V., Schaming, M., and Tissot, J.D., 1989. Déformation compressive d'un bassin intra-arc dans un contexte de collision ride/arc: le bassin d'Aoba, arc des Nouvelles-Hébrides. C. R. Acad. Sci. Ser. 2 , 308:239-245.

Fisher, M.A., Falvey, D.A., and Smith, G.L., 1988. Seismic stratigraphy of the summit basins of the New Hebrides island arc. In Greene, H.G., and Wong, F.L. (Eds.), Geology and Offshore Resources of Pacific Island ArcsVanuatu Region. Circum-Pac. Counc. Energy Miner. Resour., Earth Sci. Ser., 8:201-223.

Gérard, M., 1993. Bassins d'arc et fossés arrière-arc dans un contexte de collision/subduction: l'arc des Nouvelles-Hébrides. Hydrothermalisme, néogenèses et diagenèse d'une série volcano-sédimentaire [Thèse de doctorat (Ph.D.)]. Univ. de Paris 11.

Greene, H.G., and Johnson, D.P., 1988. Geology of the Central Basin region of the New Hebrides Arc inferred from single-channel seismic-reflection data. In Greene, H.G., and Wong, F.L. (Eds.), Geology and Offshore Resources of Pacific Island Arcs-Vanuatu Region. Circum-Pac. Counc. Energy Miner. Resour., Earth Sci. Ser., 8:177-200.

Greene, H.G., Macfarlane, A., and Wong, F.L., 1988. Geology and offshore resources of Vanuatu-introduction and summary. In Greene, H.G., and Wong, F.L. (Eds.), Geology and Offshore Resources of Pacific Island Arcs-Vanuatu Region. Circum-Pac. Counc. Energy Miner. Resour., Earth Sci. Ser., 8:1-28.

Holmes, M.L., 1988. Seismic refraction measurements in the summit basins of the New Hebrides Arc. In Greene, H.G., and Wong, F.L. (Eds.), Geology and Offshore Resources of Pacific Island Arcs - Vanuatu Region. CircumPac. Counc. Energy Miner. Resour., Earth Sci. Ser., 8:163-176.

Houtz, R., and Ewing, J., 1976. Upper crustal structure as a function of plate age. J. Geophys. Res., 81:2490-2498.

Ibrahim, A.K., Pontoise, B., Latham, G.V., Larue, B.M., Chen, T., Isacks, B., Récy, J., and Louat, R., 1980. Structure of the New Hebrides Arc-Trench System. J. Geophys. Res., 85:253-265.

Katz, H.R., 1988. Offshore geology of Vanuatu-previous work. In Greene, H.G., and Wong, F.L. (Eds.), Geology and Offshore Resources of Pacific Island Arcs-Vanuatu Region. Circum-Pac. Counc. Energy Miner. Resour., Earth Sci. Ser., 8:93-122.
Larue, B.M., Pontoise, B., Malahoff, A., Lapouille, A., and Latham, G.V., 1982. Bassins marginaux actifs du Sud-Ouest Pacifique: Plateau Nord Fidjien, Bassin de Lau. In Equipe de Géologie-Géophysique du Centre ORSTOM de Nouméa. Contrib. Etude Geodyn. Sud-Ouest Pacifique. Trav. Doc. I'ORSTOM, 147:361-406.

Latham, G.V., Donoho, P.L., Griffiths, K.H., Roberts, A., and Ibrahim, A.B.K., 1978. The Texas ocean-bottom seismograph. Proc. 1Oth Offshore Technol. Conf., 2:1467-1476.

Louat, R., and Pelletier, B., 1989. Seismotectonics and present-day relative plate motions in the New Hebrides-North Fiji basin region. Tectonophysics, 167:41-55.

Macfarlane, A., Carney, J.N., Crawford, A.J., and Greene, H.G., 1988. Vanuatu-a review of the onshore geology. In Greene, H.G., and Wong, F.L. (Eds.), Geology and Offshore Resources of Pacific Island Arcs-Vanuatu Region. Circum-Pac. Counc. Energy Miner. Resour., Earth Sci. Ser., $8: 45-91$.

Mitchell, A.H.G., and Warden, A.J., 1971. Geological evolution of the New Hebrides island arc. J. Geol. Soc. London, 127:501-529.

Monjaret, M.C., 1989. Le magmatisme des fossés à l'arrière de l'arc des Nouvelles-Hébrides (Vanuatu). (Campagne Seapso 2 du NO Jean Charcot). Implications géodynamiques: chronologie, pétrologie, géochimie [Thèse de doctorat (Ph.D.)]. Univ. Bretagne Occidentale, 1.

Nakamura, Y., Donoho, P.L., Roper, P.H., and McPherson, P.M., 1987. Largeoffset seismic surveying using ocean-bottom seismographs and air guns: instrumentation and field technique. Geophysics, 52:1601-1611.

Orcutt, J.A., 1987. Structure of the Earth: oceanic crust and uppermost mantle. Rev. Geophys., 25:1177-1196.

Pontoise, B., 1984. Résultats de sismique réfraction dans la partie centrale de l'arc insulaire des Nouvelles-Hébrides. Rap. ORSTOM.

Pontoise, B., Latham, G.V., and Ibrahim, A.B.K., 1982. Sismique réfraction: structure de la croute aux Nouvelles-Hébrides. In Equipe de GéologieGéophysique du Centre ORSTOM de Nouméa. Contrib. Etude Geodyn. Sud-Ouest Pacifique. Trav. Doc. ORSTOM, 147:79-90.

Pontoise, B., and Tiffin, D., 1987. Seismic refraction results over the d'Entrecasteaux zone west of the New Hebrides arc. Geodynamique, 2:109-120.

Roca, J.L., 1978. Contribution à l'étude pétrologique et structurale des Nouvelles-Hébrides [Thèse de doctorat (Ph.D.)]. Univ. Sciences et Techniques du Languedoc.

Sage, F., and Charvis, P., 1991. Structure profonde de la transition arc-insulaire bassin marginal dans le nord des Nouvelles-Hébrides (Vanuatu, Pacifique sud-ouest). C. R. Acad. Sci. Ser. 2, 313:41-48.

Spudich, P., and Orcutt, J., 1980. A new look at the seismic velocity structure of the oceanic crust. Rev. Geophys. Space Phys., 18:627-645.

Taylor, F.W., 1992. Quaternary vertical tectonics of the central New Hebrides Island Arc. In Collot, J.-Y., Greene, H.G., Stokking, L.B., et al., Proc. ODP, Init. Repts., 134: College Station, TX (Ocean Drilling Program), 33-42.

Taylor, F.W., Frohlich, C., Lecolle, J., and Strecker, M.R., 1987. Analysis of partially emerged corals and reef terraces in the central Vanuatu arc: comparison of contemporary coseismic and nonseismic with Quaternary vertical movements. J. Geophys. Res., 92:4905-4933.

White, R.S., Detrick, R.S., Sinha, M.C., and Cormier, M.H., 1984. Anomalous seismic crustal structure of oceanic fracture zones. Geophys. J. R. Astron. Soc., 79:779-798.

White, R.S., McKenzie, D., and O'Nions, R.K., 1992. Oceanic crustal thickness from seismic measurements and rare earth element inversions. $J$. Geophys. Res., 97:19683-19715.

Date of initial receipt: 28 April 1992

Date of acceptance: 6 October 1993 Ms 134SR-032 